Article

\title{
Bioeconomy Strategies: Contexts, Visions, Guiding Implementation Principles and Resulting Debates
}

\author{
Rolf Meyer \\ Institute for Technology Assessment and Systems Analysis (ITAS), Karlsruhe Institute of Technology (KIT), \\ 76133 Karlsruhe, Germany; rolf.meyer@kit.edu; Tel.: +49-721-608-24868
}

Academic Editor: Vincenzo Torretta

Received: 24 May 2017; Accepted: 12 June 2017; Published: 15 June 2017

\begin{abstract}
Over the last decade, bioeconomy policies, guided by integrated bioeconomy strategies, have developed. This paper presents a systematic and comparative analysis of official bioeconomy strategies of the EU, Germany, OECD, Sweden and the USA with regard to their context, visions and guiding implementation principles. In an additional step, the relationship between these strategies and important scientific and societal debates around bioeconomy is assessed. In conclusion, five major stumbling blocks for the further development of the bioeconomy are worked out. First, there is the risk of disappointment because far-reaching promises of the strategies are difficult to achieve. Second, the bioeconomy is not the only way to a low carbon economy so alternatives could impede the desired development. Third, persistent conflicts between the different uses of biomass for food, material and energy production could lead to unstable policy support with short-term shifts. Fourth, a broader success of new bioeconomy value chains could trigger new societal conflicts over bioeconomy if efficiency gains, cascading use, residue use and sustainability certification are not sufficient to ensure a sustainable supply of biomass. Fifth, the acceptance of bioeconomy could be compromised if bioeconomy policies continue to ignore the on-going societal debates on agriculture and food.
\end{abstract}

Keywords: bioeconomy; bio-based economy; strategies; visions; transformation; sustainability; biomass; vision assessment

\section{Introduction}

Over the last ten years, bioeconomy has become an important issue in research and innovation policy making, especially in industrialised countries. However, the term "bioeconomy" was already introduced in the early 1970s by Nicholas Georgescu-Roegen, in the context of his work on applying the thermodynamic law of entropy to economic processes [1]. This first understanding of bioeconomy was based on the insight that the economic process has physical and biological roots and cannot ignore their limitations [2]. The current bioeconomy debates and activities have completely different roots.

Starting points are the mergers between international biotech, chemical, pharmaceutical and agribusiness companies [3], tremendous advances in biological sciences [4], especially in genetics and molecular technologies, and the increasing biomass demand for non-food applications in energy and chemistry markets [5]. Not the limits of growth, but new growth possibilities are now in the focus. The new idea of a bioeconomy was taken up early by the OECD and the EU [6]. Today, bioeconomy policies are in different stages of development around the world. Many countries have a tradition of biotechnology and biofuel policies, and bioeconomy policy in many of these countries is restricted to strategies for these subdomains [7]. The number of countries with an integrated bioeconomy strategy including all facets of the bioeconomy is restricted. In the EU, only Finland, Flanders, Germany and Sweden have such an integrated strategy [8], and more recently also France and Spain.

The German Bioeconomy Council has provided a systematic overview and description of bioeconomy activities worldwide, specifically of the bioeconomy-specific strategies and measures 
notified by governments and their agencies, based on publicly accessible documents and statements and Internet information $[9,10]$. As part of the EU bioeconomy strategy, the Standing Committee on Agricultural Research (SCAR) has conducted a survey on the status of bioeconomy policy implementation in the Member States, based on a questionnaire filled out by 18 EU Member States $[8,11]$. Furthermore, a restricted number of papers present a comparison of national and international bioeconomy strategies [12] and of national, regional and industrial strategies in Europe [13-15]. These analyses still have a strong descriptive component, while identifying some strengths and weaknesses of the strategies.

The aim of this paper is to present a systematic and comparative analysis of important official bioeconomy strategies as key instruments for structuring and promoting this new policy field. A bioeconomy strategy is generally not a single and isolated document. In fact, it has a history and is embedded in the overall research and innovation approach of the respective government. Therefore, the paper will work out the development and context of the individual bioeconomy strategies. In these strategies, bioeconomy is conceptualised in different ways, associated with different expectations. In the following, they are analysed and compared, and the underlying visions are identified. This is done by applying a vision assessment approach [16,17]. The next part of this article looks at the principles and guidelines for the implementation of the strategies and for the development of the bioeconomy. Based on these analyses, the relationship between key elements of the strategies and important scientific and societal debates around bioeconomy is assessed. Furthermore, the relevance of these debates for the future implementation of the bioeconomy strategies is discussed. The article finally points out five major stumbling blocks for the future development of the bioeconomy.

\section{Approach}

The research on bioeconomy strategies included several steps: The first step was the sampling and selection of strategies. An overview of existing bioeconomy strategies was obtained from literature [8-10] and an Internet enquiry. Analysis was restricted to integrated bioeconomy strategies, since it was aimed at analysing and comparing fully developed bioeconomy policies. The international and European strategies of OECD and EU, respectively, all German strategies and, for further comparison, the integrated strategies of Sweden and the USA were included (Table 1). The strategies were approved and published over a period of four years, from 2009 to 2013. 
Table 1. Overview of analysed bioeconomy strategies.

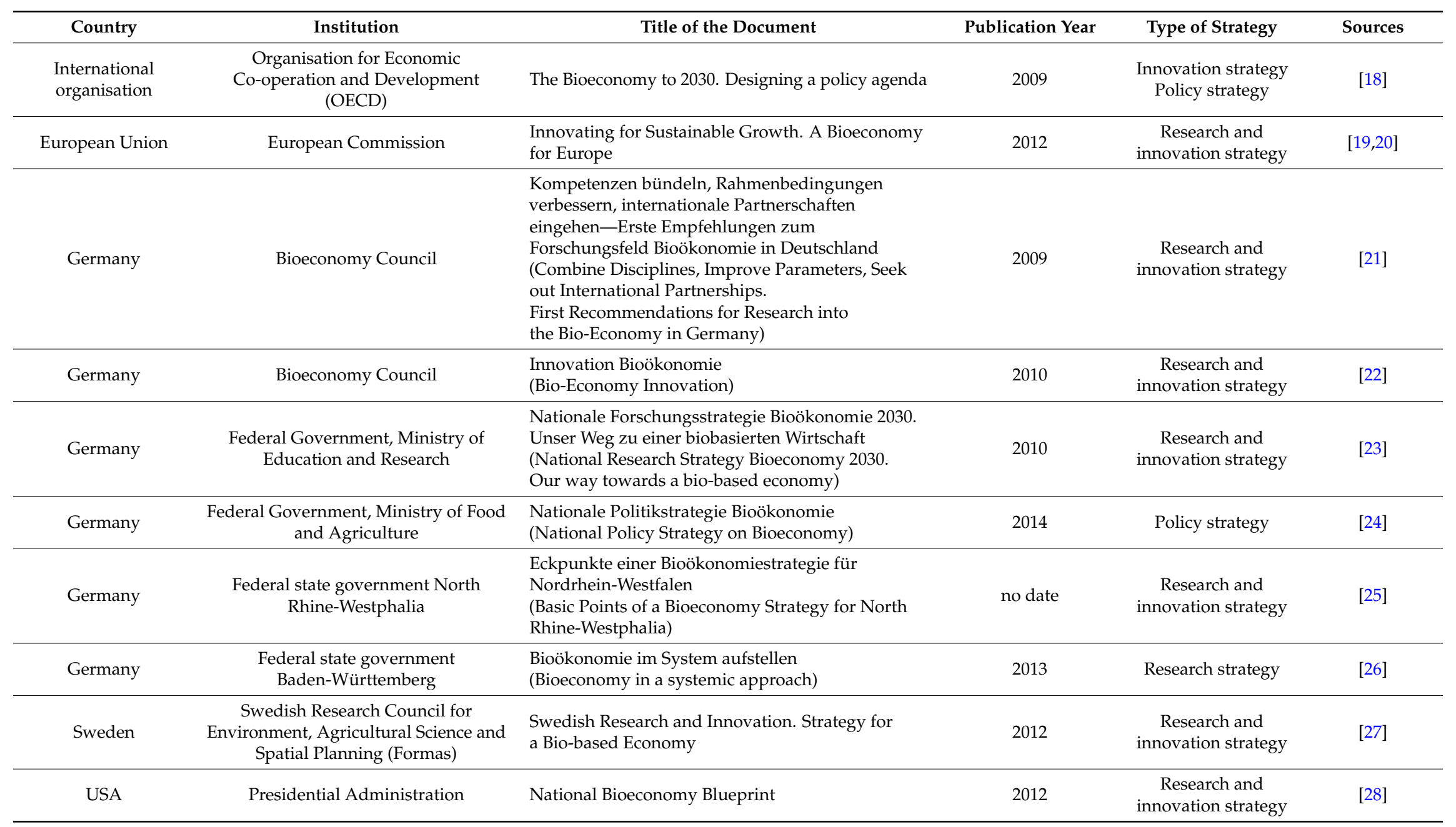


The next step was the reconstruction of the process that led to the respective strategy. Three aspects were addressed: changes in the understanding and focus of bioeconomy, connections to other governmental strategies and policies, and participants involved in the drafting process. Thereby, context and actors were analysed. Then, the definitions of bioeconomy used in the strategies were assessed, and a categorisation of definitions was conducted. The different understandings of bioeconomy influence the system boundaries and, for instance in economic assessments, what kind of economic activities should be considered as part of the bioeconomy [29]. More generally, the definition of bioeconomy has implications on the areas of activity.

Socio-technical visions have become an increasingly important element in innovation and transformation processes and their governance. This is notably the case for complex and far-reaching new and emerging technologies (e.g., nanotechnology), and for the transformation of well-established large socio-technical systems (e.g., energy system transition) [17,30]. Visions are an instrument of communication and coordination, addressing actors in the research and innovation systems. At the same time, they intend to affect societal spheres and groups, promoting new objectives and promising solutions for societal problems (e.g., climate change). Visions often present target innovations as radical innovations or disruptive developments [31]. Visions also play-explicitly or implicitly—an important role in the bioeconomy strategies. The vision assessment starts from the specific set of expectations or promises made in each strategy, from which the overarching visions are then deduced and clustered.

The following step was to analyse the principles and guidelines for the implementation of strategies and the development path of the bioeconomy. These formulate requirements and prerequisites. An example of such a principle is sustainability, which has become established in most policy areas. In the context of bioeconomy strategies, principles and guidelines play a prominent role in biomass use, on the one hand, and the organisation of research and innovation, on the other hand.

The assessment of the relationship between bioeconomy strategies and important scientific and societal debates around bioeconomy was based on a review of the relevant literature. The aim of this analysis was to identify divergent viewpoints regarding the opportunities and barriers for the realisation of the desired bioeconomy development.

\section{Analysis}

\subsection{Formation and Context of Bioeconomy Strategies}

The concept of bioeconomy originates from the life sciences and biotechnology spheres [32]. The national and international policy-making processes leading to bioeconomy strategies were more or less complex, partly with changing perspectives. This chapter gives a short overview of these processes and a description of their relationship to overall governmental policies and actors involved.

\subsubsection{International and European Strategies}

The report "The Bioeconomy to 2030: Designing a Policy Agenda" [18] is the result of an OECD foresight project as part of the OECD International Futures Programme (IFP), which examines long-term futures. The work was overseen by a Steering Group with representatives from governments, companies and international organisations, and was supported by experts from research and industry. The report was drafted by the OECD Secretariat.

A common research policy and funding in the EU started in 1982 with the first research programme on biotechnology (Biomolecular Engineering Programme (BEP)) of the European Commission. A number of biotechnology research programmes followed over the next three decades [33]. In the year 2005, the term "Knowledge-Based Bio-Economy (KBBE)" was introduced by the Commission in the context of the conference "New Perspectives on the Knowledge-Based Bio-Economy" as the process of "transforming life science knowledge into new, sustainable, eco-efficient and competitive products" [34]. The additive "knowledge-based" had its origin in the Lisbon strategy, 
which stated the strategic objective to transform the EU into "the most competitive and dynamic knowledge-based economy in the world" until 2010 [35].

At the conference "En Route to the Knowledge-Based Bio-Economy" of the German Presidency in 2007, the so-called Cologne Paper was presented. It was drafted by experts from industry and research and is focused on perspectives of biotechnology until the year 2030 [36]. For the conference "The knowledge based bio-economy towards 2020" in 2010 under the Belgian Presidency [20], a report on achieved progress and outstanding challenges was prepared [37]. With this report, the focus on biotechnology was abandoned, and new policy areas such as the Common Agricultural Policy and sustainability criteria were addressed. The shift from biotechnology to societal challenges was reinforced in 2011 by the White Paper "The European Bioeconomy in 2030" [38], which sets out a vision for a smart, sustainable and inclusive European bioeconomy. The paper is the result of a discussion process of experts from nine separate Technology Platforms covering different aspects of the bioeconomy.

This process concluded with the approval of the EU bioeconomy strategy [19], accompanied by a Commission staff working document [20] providing background information and a detailed action plan. This strategy is embedded in the overall strategy "Europe 2020" [39], the successor of the Lisbon Strategy. The bioeconomy should contribute to the two flagship initiatives "Innovation Union" and "A Resource Efficient Europe" of the Europe 2020 Strategy [19,40]. In preparation of the bioeconomy strategy, the European Commission organised a public consultation and received over 200 responses [41,42]. An essential instrument for strategy implementation is the EU research and innovation programme "Horizon 2020" [43] for the period 2014 to 2020, especially the part "Biotechnology" in the section Industrial Leadership and the part "Food Security, Sustainable Agriculture and Forestry, Marine, Maritime and Inland Water Research and the Bioeconomy" in the section Societal Challenges, with a dedicated budget for the latter of 4.1 billion euros for the period 2014 to 2020 [20].

\subsubsection{German Strategies}

The German policy development on bioeconomy started in 2009 with the appointment of the Bioeconomy Council by the Federal Ministries for Education and Research and for Food and Agriculture for a period of three years. In 2012, a new council was appointed with a broader composition of members who should represent the areas of economy, science and society. The latter, however, is only covered by social scientists. The Bioeconomy Council published its first recommendations for bioeconomy research in Germany in 2009 [21], with a focus on research organisation. This first short strategic paper was followed a year later by an extensive report [22]. The Council was supported in the drafting of this report by external experts. The report works out three broad topics for German bioeconomy research together with detailed recommendations for programming.

In the same year, 2010, the "National Research Strategy Bioeconomy 2030" [23] was released. This strategy was drafted under the leadership of the Federal Ministry for Education and Research in cooperation with six other federal ministries. There are clear analogies with the recommendations of the Bioeconomy Council, without explicit reference to them. In the framework of the strategy, an overall research funding volume of 2.4 billion euros until 2016 is assigned [44] (p. 2). This bioeconomy strategy is part of the High-Tech Strategy of the Federal Government, which aims to initiate cross-ministry innovation initiatives and is oriented on top priority societal challenges [45].

The "National Policy Strategy Bioeconomy" [24] was adopted by the Federal Government in 2013. The policy strategy was prepared by the Federal Ministry of Food and Agriculture in cooperation with four other ministries and the Bioeconomy Council. The structure differs from the research strategy due to addressing different policy areas. The policy strategy is embedded in a number of other strategies of the Federal Government, for example the sustainability strategy and the energy concept [24] (p. 16).

Additionally, two federal states of Germany have their own bioeconomy strategies. The federal state of North Rhine-Westphalia started their bioeconomy activities with a study of potentials [46], 
which gives an overview of the potential of life sciences and their industrial applications in North Rhine-Westphalia. The Ministry for Innovation, Science and Research of North Rhine-Westphalia has formulated basic points for a bioeconomy strategy [25]. This short, five-page paper sketches objectives, main application areas and the intended policy approach. It contributes to the implementation of the overall research strategy [47]—a framework programme for all research activities of the state government, aimed at research for sustainable development in key areas of societal challenges.

The strategy of the Baden-Württemberg Ministry of Science, Research and Art of 2013 [26] was developed by a working group of scientists from a broad spectrum of disciplines relevant to bioeconomy, in cooperation with partners from industry. The strategy includes an extensive assessment of the current research landscape of Baden-Württemberg relevant to bioeconomy, including a SWOT (strengths and weaknesses, opportunities and threats) analysis and the reasoning and description of three research topics to be funded.

\subsubsection{Strategies of Other Countries}

The Swedish research and innovation strategy for bioeconomy was launched in 2012 [27]. The strategy was prepared upon request from the Swedish Government by FORMAS (The Swedish Council for Environment, Agricultural Sciences and Spatial Planning), in consultation with VINNOVA (Swedish Governmental Agency for Innovation Systems) and the Swedish Energy Agency. A dialogue with representatives from research, companies and industry associations was conducted during the drafting process. Bioeconomy research and innovation activities are divided among many institutions and organisations in Sweden [48].

The US national bioeconomy strategy [28] from 2012 details administration-wide steps to harnessing biological research innovations. The strategy was drafted by the Office of Science and Technology Policy and the Executive Office of the President, under participation of different federal agencies. Half a year before, a public consultation had been started [49]. Overall, 135 responses were received from individual persons and institutions [50], predominantly from science and industry.

\subsection{Definition of Bioeconomy}

The applied definition of bioeconomy is strongly connected with the overall understanding of bioeconomy in the respective strategy (Table 2). Two basic approaches can be distinguished:

- Bioeconomy in a narrower sense: Technology-oriented definitions, such as in the strategies of the OECD [18] and the USA [28], restrict bioeconomy to the development and application of modern biotechnologies and scientific findings from life sciences. In this understanding, new applications in the health sector such as personalised medicine and biomedicine are part of the bioeconomy. Biomass, as a resource, does not play a prominent role in these strategies. The economic relevance of the bioeconomy results from its high innovation potential. Bioeconomy is regarded as an already existing reality, which should be supported and expanded to make optimal use of its economic potential.

- Bioeconomy in a broader sense: Definitions focussing on the resource biomass and the economic sectors involved, partly with normative elements, are used in strategies which emphasise the transition from a petroleum-based to a bio-based economy [19-27]. In this understanding, the bioeconomy encompasses the production, processing or use of biological resources in whatever form $[21,22]$. In some of the strategies $[21,23,24,26]$, relevant sectors are listed, ranging from agriculture and forestry to food, timber, chemical, pharmaceutical and energy industries as well as their respective trade sectors, with slight variations from strategy to strategy. The current economic relevance of the bioeconomy is increased with the inclusion of traditional economic sectors such as, for example, agriculture and the food industry. At the same time, the health sector is no longer addressed, except in one strategy [25]. With the envisioned transformation of the economic resource base, the bioeconomy represents a development goal that can only 
be realised in the future. In this context, the term bio-based economy is used as an equivalent to bioeconomy in some strategies $[23,24,26,27]$. Both terms are understood as synonyms.

The term "knowledge-based bioeconomy (KBBE)" was first coined in the EU and goes back to the Lisbon strategy. The label "knowledge-based" has lost relevance at the EU level but is still used explicitly in some national strategies, and resonates in others because all strategies place emphasis on new scientific knowledge and technologies and their translation into economically exploitable innovations.

Table 2. Bioeconomy definitions in the bioeconomy strategies.

\begin{tabular}{llcc}
\hline \multicolumn{1}{c}{ Strategies } & & Definition Relating To \\
\cline { 2 - 4 } & $\begin{array}{c}\text { Resource Basis } \\
\text { Biomass }\end{array}$ & $\begin{array}{c}\text { Involved Economic } \\
\text { Sectors }\end{array}$ & $\begin{array}{c}\text { Technology } \\
\text { (Biotechnology) }\end{array}$ \\
\hline International strategies & & $\sqrt{ }$ & $\sqrt{ }$ \\
\hline OECD 2009 [18] & $\sqrt{ }$ & $\sqrt{ }$ \\
EC 2012 [19,20] & & - & - \\
\hline German strategies & $\sqrt{ }$ & $\sqrt{ }$ \\
\hline Bioeconomy Council 2009 [21] & $\sqrt{ }$ & - \\
Bioeconomy Council 2010 [22] & $\sqrt{ }$ & $\sqrt{ }$ \\
Federal Ministry of Education and Research 2010 [23] & $\sqrt{ }$ & - \\
Federal Ministry of Food and Agriculture 2014 [24] & $\sqrt{ }$ & - \\
Federal state government North Rhine-Westphalia [25] & & - \\
Federal state government Baden-Württemberg 2013 [26] & $\sqrt{ }$ & - \\
\hline Strategies of other countries & - & - \\
\hline Sweden 2012 [27] & & - \\
USA 2012 [28] & & \\
\hline
\end{tabular}

\subsection{Expectations and Visions}

The strategies include a number of expectations placed upon the bioeconomy (Table 3). All strategies share the expectation that the bioeconomy will make an important contribution to economic growth and international competitiveness of the respective economic system. In addition, the creation of new jobs is in some strategies explicitly expected as a consequence of economic growth. The expectations of the bioeconomy thus stand in the tradition of past expectations of biotechnology, which was attributed great implementation and commercialisation potential already at an early stage [51] (p. 64). The strategies defining bioeconomy in a broader sense expand the promises of economic growth to traditional sectors of the bioeconomy. 
Table 3. Visions and expectations in the bioeconomy strategies.

\begin{tabular}{|c|c|c|c|c|c|c|c|c|c|c|}
\hline \multirow[b]{2}{*}{ Strategies } & \multicolumn{2}{|c|}{ Vision } & \multicolumn{8}{|c|}{ Expectations } \\
\hline & $\begin{array}{l}\text { Biotechnology- } \\
\text { Centred }\end{array}$ & $\begin{array}{l}\text { Transformation- } \\
\text { Centred }\end{array}$ & $\begin{array}{l}\text { Structural Change } \\
\text { of Resource Basis }\end{array}$ & $\begin{array}{c}\text { Innovative } \\
\text { Knowledge Society }\end{array}$ & $\begin{array}{l}\text { Answer to Global } \\
\text { Challenges }\end{array}$ & $\begin{array}{l}\text { Economic Growth and } \\
\text { Competitiveness }\end{array}$ & $\begin{array}{l}\text { Biotechnology as } \\
\text { Key Innovation }\end{array}$ & $\begin{array}{c}\text { Global } \\
\text { BioEconomy }\end{array}$ & $\begin{array}{l}\text { Revolution in } \\
\text { Health Sector }\end{array}$ & $\begin{array}{c}\text { Societal } \\
\text { Acceptance }\end{array}$ \\
\hline \multicolumn{11}{|c|}{ International strategies } \\
\hline $\begin{array}{l}\text { OECD } 2009[18] \\
\text { EC } 2012[19,20]\end{array}$ & $\sqrt{ }$ & $\bar{v}$ & $\bar{v}$ & - & $\sqrt{ }$ & $\sqrt{ }$ & $\sqrt{ }$ & $\sqrt{ }$ & $\sqrt{ }$ & $\sqrt[V]{ }$ \\
\hline \multicolumn{11}{|l|}{ German strategies } \\
\hline $\begin{array}{l}\text { BÖR 2009 [21] } \\
\text { BÖR 2010 [22] } \\
\text { BMBF 2010 [23] } \\
\text { BMEL 2014 [24] } \\
\text { NRW [25] } \\
\text { BW 2013 [26] }\end{array}$ & $\begin{array}{l}- \\
- \\
- \\
-\end{array}$ & $\begin{array}{l}\sqrt{ } \\
\sqrt{ } \\
\sqrt{ } \\
\sqrt[V]{ }\end{array}$ & $\begin{array}{l}\sqrt{ } \\
\sqrt{ } \\
\sqrt{ } \\
\sqrt{ } \\
\sqrt{ }\end{array}$ & $\begin{array}{l}\sqrt{ } \\
- \\
\sqrt{ } \\
- \\
\sqrt{ }\end{array}$ & $\begin{array}{l}\sqrt[V]{ } \\
\sqrt{ } \\
\sqrt{ } \\
\sqrt{ }\end{array}$ & $\begin{array}{l}\sqrt{ } \\
\sqrt{ } \\
\sqrt{ } \\
- \\
\sqrt{ }\end{array}$ & $\begin{array}{l}\sqrt[V]{ } \\
\sqrt{ } \\
\sqrt{ } \\
\sqrt{ }\end{array}$ & $\begin{array}{l}\sqrt{ } \\
- \\
- \\
- \\
-\end{array}$ & $\begin{array}{c}(\sqrt{ }) \\
- \\
- \\
- \\
(\sqrt{ })\end{array}$ & $\begin{array}{l}- \\
- \\
\sqrt{ } \\
\sqrt{ } \\
-\end{array}$ \\
\hline \multicolumn{11}{|c|}{ Strategies of other countries } \\
\hline $\begin{array}{l}\text { Sweden } 2012 \text { [27] } \\
\text { USA } 2012 \text { [28] }\end{array}$ & $\bar{v}$ & $\sqrt{ }$ & $\sqrt{ }$ & 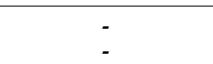 & $\overline{-}$ & $\sqrt{ }$ & $\bar{v}$ & - & $\bar{v}$ & - \\
\hline
\end{tabular}

Notes: OECD, Organisation for Economic Co-operation and Development; EC, European Commission; BÖR, German Bioeconomy Council; BMBF, German Federal Ministry of Education and Research; BMEL, German Federal Ministry of Food and Agriculture; NRW, Federal state government North Rhine-Westphalia; BW, Federal state government Baden-Württemberg. 
The economic expectations are closely linked to the aim of playing a leading role in technology development (explicitly in $[23,26])$. A common understanding in all documents is that new scientific findings and technological developments shape the bioeconomy and should be supported. In the German federal research strategy, the bioeconomy is also embedded in a more comprehensive vision of a "free, dynamic and innovative knowledge society" [23] (p. 14). Biotechnology is a constitutive element in strategies with a bioeconomy definition in a narrower sense $[18,28]$, and is regarded as a key innovation in most strategies based on a broader understanding of the bioeconomy (see also Table 3). All strategies are characterised by a technic-centred understanding of innovation.

Almost all strategies expect the bioeconomy to make an important contribution to societal or global challenges. Food security, preservation of resources, climate and environmental protection and health problems are mentioned as examples. The finite nature of fossil resources and climate change are the argumentative background for the aspired transition from an economy based on fossil fuels to a bio-based economy [23] (p. 4). The strategies differ in the extent to which they envision the replacement of fossil-based resources with bio-based resources. This ranges from an unspecified bio-based economy $[23,25,26]$ over reduced dependence from fossil resources [19] and moving towards a post-fossil age [21] to conversion to an economy based on renewable resources in general [24]. The latter German policy strategy introduces a relativisation both in quantitative terms-only partial replacement of fossil resources-and in qualitative terms-biomass as part of the overall renewable resources. At the same time, the disruptive character of bioeconomy is highlighted as a far-reaching and comprehensive societal transformation process that must be accompanied by social, economic, political and ecological research [52]. Based on the transformation perspective, some of the strategies address conflicts of objectives, side effects and governance issues [24,26,27].

Half of the strategies expect the bioeconomy to take on a global character, with two different lines of argumentation: First, the bioeconomy is considered as part of a global strategy for sustainable resource management [19]. The focus is on solving global challenges. The second approach conceptualises bioeconomy as global phenomenon. Here, emphasis is placed on the global interconnectedness of biomass resources, value added chains and technologies with international division of labour in research, production and markets $[18,22,24]$. Two strategies expect fundamental advances in the health sector in the context of bioeconomy $[18,28]$. It is expected that biotechnologies will dominate the development of diagnostics, vaccines, drugs and therapies which will open new possibilities for the treatment of diseases. The strategy for North Rhine-Westphalia includes the health sector because of the regional relevance of the respective industries [25].

In the past, biotechnologies were sometimes the subject of controversial public debate, especially in the case of green genetic engineering. Several strategies formulate expectations on societal acceptance of bioeconomy in the future. The German research strategy expresses the expectation that biotechnological progress and globalisation will be regarded positively as societal chances [23]. This is combined with a classical model of producing acceptance: Science and industry should inform and convince the general public of the benefits of the bioeconomy. In the last years, there has been a gradual shift to a stronger accentuation of participative dialogues in which citizens and end-users should be given the possibility to articulate their needs and expectations of developments in bioeconomy.

In summary, the set of expectations in the strategies can be clustered into two basic visions (Table 3):

- Biotechnology-centred vision: life science and biotechnology as drivers of innovation

- Transformation-centred vision: shift to a bio-based economy

The biotechnology-centred vision sketches a future where new findings in life science and the resulting technologies and innovations lead to economic growth, improved international competitiveness and additional jobs. This vision is a continuation of the promises and expectations associated with biotechnology in the last decades. The expectation is that biotechnology will contribute to a significant share of economic output, with applications across economic sectors 
and converging technologies. Scientific knowledge, technological developments and commercial innovations are seen as drivers of the bioeconomy, influenced by government policies on public research support, regulatory conditions, intellectual property rights and promotion of human resources. Scientific breakthroughs (e.g., in synthetic biology) that lead to disruptive and radical innovations with corresponding effects are considered possible in the foreseeable future. The main objective is to achieve competitive advantages and a leading position in technology and markets.

The transformation-centred vision presents bioeconomy as an answer to global challenges such as climate change, food security and the finite nature of and dependence on fossil fuels. At the heart of the vision is a structural transition to a bio-based economy. The aspired shift ranges from biomass as the new resource base in unspecified manner to biomass as part of total renewable resources. Initially, the EU and Germany followed a biotechnology-centred vision; the current transformation-centred vision is the result of a longer reshaping process. Expectations of economic growth and enhanced international competitiveness are still of high relevance, but are now combined with promises of improved sustainability. The strong focus on innovation through research and technology development is maintained. Besides biotechnology as a key technology, a broad spectrum of technology approaches is included. These strategies take into account conflicts of goals and competition for land use that may arise from such a transformation. This vision corresponds with an understanding of the bioeconomy in a broader sense, including all economic sectors dealing with biological resources. However, the health sector and health biotechnology are now excluded. The transformation approach requires various specific policy areas to be addressed as well as a coherent policy framework.

\subsection{Guiding Principles for Implementation}

In regard to their implementation, the bioeconomy strategies have developed to a different degree guiding principles for the supply and use of biomass and for the organisation of research and innovation.

\subsubsection{Guiding Principles for the Supply and Use of Biomass}

Overall, sustainability is the most important guiding principle in the bioeconomy strategies in regard to supply and use of biomass (Table 4). Different understandings of the relationship between the bioeconomy and sustainability were identified in the scientific literature [53]:

- $\quad$ sustainability as an inherent characteristic;

- conditional benefits for sustainability;

- tentative criticism pointing out potential sustainability problems; and

- disadvantageous without positive impact on sustainability.

The understanding of sustainability in the bioeconomy strategies can be allocated to the first two categories. Two strategies $[18,28]$ do not explicitly mention the issue of sustainability, and one strategy [21] more or less equates bioeconomy with sustainability. However, the prevailing view is that the bioeconomy will have positive sustainability effects if the right conditions are created and appropriate measures are taken. Consequently, sustainability is stipulated as a goal and guiding principle.

Among the potential sustainability problems discussed in the strategies, primary production of biomass takes a prominent place. This includes

- sustainable use of natural resources such as soil, water, nutrients, genetic resources and biodiversity [19,22,24-27];

- sustainable agricultural production, mentioning plant breeding, crop production and agricultural technologies (e.g., precision farming) [23,24]; and

- evaluation and improvement of different agricultural production systems in terms of sustainability [22,23]. 
Table 4. Guiding principles for the supply and use of biomass in the bioeconomy strategies.

\begin{tabular}{|c|c|c|c|c|c|c|}
\hline Strategies & Sustainability & Priority for Food & $\begin{array}{l}\text { Prevention of Land } \\
\text { Use Conflicts }\end{array}$ & $\begin{array}{l}\text { Priority for Residual } \\
\text { and Waste Biomass }\end{array}$ & $\begin{array}{l}\text { Cascading Use and } \\
\text { Coupled Use }\end{array}$ & $\begin{array}{l}\text { Consideration of Ecological } \\
\text { and Socio-Economic Impacts }\end{array}$ \\
\hline \multicolumn{7}{|c|}{ International strategies } \\
\hline OECD 2009 [18] & - & - & - & - & - & - \\
\hline EC $2012[19,20]$ & $\sqrt{ }$ & - & - & - & - & - \\
\hline \multicolumn{7}{|l|}{ German strategies } \\
\hline BÖR 2009 [21] & $\sqrt{ }$ & - & - & - & - & - \\
\hline BÖR 2010 [22] & $\sqrt{ }$ & - & - & - & $\sqrt{ }$ & $\sqrt{ }$ \\
\hline BMEL 2014 [24] & $\sqrt{ }$ & $\sqrt{ }$ & $\sqrt{ }$ & $\sqrt{ }$ & $\sqrt{ }$ & $\sqrt{ }$ \\
\hline NRW [25] & $\sqrt{ }$ & - & - & - & $\sqrt{ }$ & - \\
\hline BW 2013 [26] & $\sqrt{ }$ & $\sqrt{ }$ & $\sqrt{ }$ & $\sqrt{ }$ & $\sqrt{ }$ & $\sqrt{ }$ \\
\hline \multicolumn{7}{|c|}{ Strategies of other countries } \\
\hline Sweden 2012 [27] & $\sqrt{ }$ & - & $\sqrt{ }$ & - & $\sqrt{ }$ & $\sqrt{ }$ \\
\hline USA 2012 [28] & - & - & - & - & - & - \\
\hline
\end{tabular}
and Research; BMEL, German Federal Ministry of Food and Agriculture; NRW, Federal state government North Rhine-Westphalia; BW, Federal state government Baden-Württemberg. 
Only one strategy addresses the issue of sustainable forestry and fishery [24]. Sustainable design of bio-based production processes and products, especially regarding biorefinery, is discussed in two strategies [24,26]. Here, accompanying research on ecological and socio-economic effects is demanded to achieve sustainability. In some strategies, the guiding principle of sustainability is supplemented by additional guidelines (Table 4):

- $\quad$ priority for food;

- prevention of land use conflicts;

- priority for residual and waste biomass;

- cascading and coupled use; and

- consideration of ecological and socio-economic impacts.

Key approaches to implementing the guiding principle of sustainability and the additional guidelines are to support technological innovation for more efficient production and use of biomass, research on sustainability implications of the bioeconomy development, and development and implementation of sustainability standards and certification. The ecological and socio-economic research on sustainability is conceptualised in two settings: (1) as an integral part of the strategy and its research clusters [26]; and (2) with separate concepts and as accompanying research. In the latter case, a strong connection to the research on technology and innovation is demanded to ensure that the strategy and the development of technologies can be adjusted. New bio-based products and markets should be supported by the development of methodology, knowledge base, criteria and standards for sustainability assessment, together with the introduction and application of certification schemes and labels $[19,20,23,24]$.

\subsubsection{Guiding Principles for the Organisation of Research and Innovation}

Seven guiding principles for organising bioeconomy research and innovation were identified (Table 5). They are broadly similar, with some specific differences in design. A systemic or holistic approach to the bioeconomy is an important guiding principle, especially in German strategies. On the one hand, this approach is conceptualised as a systemic understanding of the bioeconomy, following guidelines such as thinking in terms of value chains, systematic analysis of changes and impacts [22-24,26]. Systemic research approaches also intend to solve conflicts of objectives. On the other hand, a systemic structure of bioeconomy research is aspired, with integration of different research areas and actors [21-23,26].

Beyond research, various existing and emerging policies are recognised in some strategies as influencing the framework conditions for the bioeconomy and creating a complex, fragmented and sometimes incoherent policy environment $[19,24]$. Consequently, the interlocking of various policy areas and the building up of a coherent policy framework for the bioeconomy are guiding principles in four strategies $[18,19,24,25]$. In the case of the federal government of Germany and the federal state North-Rhine Westphalia, this is concretised by the establishment of an inter-ministerial working group [24,25].

Most strategies call for interdisciplinary bioeconomy research, focusing on three aspects: interdisciplinary competencies, interdisciplinary cooperation and interdisciplinary knowledge. Only two strategies explicitly include transdisciplinary research approaches $[25,26]$. The majority of strategies include proposals for building structures for high-quality vocational training and education of young academics. Advancement of systemic thinking and development of interdisciplinary scholarship are in some strategies emphasised $[20-22,24,26]$ and seen as important preconditions for the development of the bioeconomy $[19,22,24,28]$. In addition, advantages in the competition for talents are intended to be achieved [22,24]. 
Table 5. Guiding principles for the organisation of research and innovation in the bioeconomy strategies.

\begin{tabular}{|c|c|c|c|c|c|c|c|}
\hline Strategies & Systemic View & $\begin{array}{c}\text { Coherent Policy } \\
\text { Framework }\end{array}$ & $\begin{array}{l}\text { Interdisciplinary } \\
\text { Research }\end{array}$ & $\begin{array}{l}\text { International } \\
\text { Cooperation }\end{array}$ & $\begin{array}{c}\text { Integration of } \\
\text { Actors }\end{array}$ & $\begin{array}{c}\text { Education and } \\
\text { Training }\end{array}$ & $\begin{array}{l}\text { Improvement of } \\
\text { Framing Conditions }\end{array}$ \\
\hline \multicolumn{8}{|c|}{ International strategies } \\
\hline OECD 2009 [18] & - & $\sqrt{ }$ & - & $\sqrt{ }$ & - & - & $\sqrt{ }$ \\
\hline EC $2012[19,20]$ & $\sqrt{ }$ & $\sqrt{ }$ & $\sqrt{ }$ & $\sqrt{ }$ & $\sqrt{ }$ & $\sqrt{ }$ & $\sqrt{ }$ \\
\hline \multicolumn{8}{|l|}{ German strategies } \\
\hline BÖR 2009 [21] & $\sqrt{ }$ & - & $\sqrt{ }$ & $\sqrt{ }$ & $\sqrt{ }$ & $\sqrt{ }$ & $\sqrt{ }$ \\
\hline BÖR 2010 [22] & $\sqrt{ }$ & - & $\sqrt{ }$ & $\sqrt{ }$ & $\sqrt{ }$ & $\sqrt{ }$ & $\sqrt{ }$ \\
\hline BMEL 2014 [24] & $\sqrt{ }$ & $\sqrt{ }$ & - & $\sqrt{ }$ & $\sqrt{ }$ & $\sqrt{ }$ & $\sqrt{ }$ \\
\hline NRW [25] & - & $\sqrt{ }$ & $\sqrt{ }$ & - & $\sqrt{ }$ & - & - \\
\hline BW 2013 [26] & $\sqrt{ }$ & - & $\sqrt{ }$ & - & $\sqrt{ }$ & $\sqrt{ }$ & - \\
\hline \multicolumn{8}{|c|}{ Strategies of other countries } \\
\hline Sweden 2012 [27] & - & - & $\sqrt{ }$ & $\sqrt{ }$ & $\sqrt{ }$ & - & - \\
\hline USA 2012 [28] & - & - & $\sqrt{ }$ & - & $\sqrt{ }$ & $\sqrt{ }$ & $\sqrt{ }$ \\
\hline
\end{tabular}


Besides interdisciplinary cooperation, close cooperation between different actors is a guiding principle in almost all strategies. Close interaction between research and economy is therefore a central element. In particular, a better linking of commercial and public research is proposed, up to explicit public-private partnerships. Involvement of societal actors is foreseen only in some of the strategies, reaching from the provision of information to stakeholders [23] over user forums [27] to dialogue processes [24-26]. These approaches correspond to the strategies' expectations regarding societal acceptance of the bioeconomy.

In most strategies, the development of international cooperation is an important guideline. Only the US strategy includes only national activities. The desired international cooperation involves different aspects such as exchange of information and knowledge transfer, international coordination of research and innovation activities, and setting up of common multinational research and technology activities. The call for international cooperation is in line with the vision of a global bioeconomy.

Finally, many strategies aim to improve the framework conditions for the bioeconomy. This includes different issues. One point is the development of a coherent policy framework for the bioeconomy (see above in this section). In the context of biotechnology, assumed legal uncertainties and innovation obstacles are addressed and their reduction is demanded. This is an important element in the strategies of the German Bioeconomy Council [22], the OECD [18] and the USA [28]. Finally, more classical instruments for the promotion of research and innovation in companies are addressed in the context of improved framing conditions [21,24,27,28].

\section{Discussion}

The bioeconomy strategies have been already a success in terms of raising awareness, mobilising funding and strengthening research networks. Besides international and national activities, a number of regional bioeconomy initiatives have been started [14] and regional innovation networks have been established. At the same time, a broad scientific and partly also societal debate on different aspects of the bioeconomy strategies has evolved. Relevant arguments from these debates on the implementation of the bioeconomy strategies and the realisation of the intended bioeconomy development are discussed in this chapter.

\subsection{Key Actors in Strategy Development and Claimed Democratic Deficit}

Experts were the key actors in the development of the official bioeconomy strategies. Two groups were identified that played a key role in the strategy drafting processes:

- $\quad$ expert group of scientists [26] or experts from research and industry [18,21,22]; and

- governmental administration [19,23-25,28] or subordinate governmental agency [27].

In the latter case, an explicitly documented or implicit involvement of experts from research and industry has taken place. Public consultations were held only during the preparation of the EU and US strategies $[19,28]$. However, the responses came almost exclusively from representatives of research and industry, while responses from civil society actors remained an exception. This is in line with the observation that civil society organisations have played a marginal role in the EU bioeconomy policy process [54]. Consequently, bioeconomy was described as an elite master narrative that is entrenched in EU-wide and national policy frameworks configured by particular research and innovation policy elites and/or bureaucracies [55]. In this line, it is argued that dissenting opinions from NGOs and trade unions have found no way to initiate a high-level debate, much less to challenge EU policy frameworks on research agendas [56]. This is also described as a democratic deficit of the bioeconomy policy $[57,58]$.

Four arguments are raised for broader societal debate and stronger involvement of societal stakeholders: 
- A bio-based economy will be associated with a broad spectrum of societal impacts. Hence, it is a democratic imperative to base bioeconomy policy on broad societal debate [57], which should also include overall visions and implementation pathways.

- NGOs are already deeply engaged in debates on biofuels for transport and on forest biomass for bioenergy production. They are likely to become important opinion formers in the implementation of the bioeconomy strategies [59]. The engagement of opinion formers such as NGOs is deemed to be important for a successful bioeconomy policy.

- The focus on (business) opportunities involves the risk that potential barriers and resistances are overlooked. The developing bioeconomy involves new actors and new branches of economic activity. This process inherently creates resistance from actors that have vested interests in the current system and try to defend the status quo [60]. Therefore, stakeholders from the traditional bioeconomy and different economic sectors should be involved.

- Consumers are generally unfamiliar with bio-based products and have positive and negative associations with "bio-based" as a general concept [61]. Positive consumer perception is seen as a precondition for a successful transition towards a bio-based economy.

The observed gradual shift to participative dialogues in same strategies is reflected in the establishment of stakeholder forums such as the EU Bioeconomy Panel [62] with members of four stakeholder groups: producers, enterprises and industry; universities, research organisations and the scientific community; public administrations; and civil society. However, the main objective of these bodies is to support the implementation process of the strategies and to facilitate interactions between different policy areas, sectors and stakeholders in the bioeconomy. Their influence on the alignment of overall strategic goals is therefore unclear, and the involvement of end-users still needs to be developed.

\subsection{Bioeconomy Strategies as Integral Part of Overall Research and Innovation Policy and Debated Neoliberal Agenda}

Bioeconomy is advertised as a new vision, but the analysis of strategies shows that the bioeconomy strategies are, as a rule, an integral part of the respective overall research and innovation policy of the governments and share important objectives with them. This is most pronounced in the EU strategy with its strong reference to the Lisbon strategy and the Europe 2020 strategy, respectively. However, the two German bioeconomy strategies of the federal government have links to other federal strategies and are embedded in the overall research and innovation policies. Therefore, they conceptualise the bioeconomy policy as a consistent part of the overall technology and innovation policy. In the last years, the integration of research and innovation policies has gained political importance. This is reflected in the bioeconomy strategies [33]. Besides the research topics, different areas of action to improve framework conditions for innovation have become part of most bioeconomy strategies, with the aim of promoting innovation. The integration of different policy areas is most advanced in the German National Policy Strategy [24].

In view of the embeddedness of the strategies, a close connection of the bioeconomy to neoliberalism as the dominant mode of governance is stated and discussed [63]. Neoliberal discourse and policies are characterised by market expansion, deregulation respectively market friendly re-regulation, privatisation of state-owned enterprises and services, and increasing influence of corporate non-state actors [63,64]. Discourse and practice in this context are guided by the aim of economic competitiveness, which is also a key element of all bioeconomy visions. Competitiveness is defined as success in international markets and is linked to innovation in both policy and academic debates [63]. The competitiveness agenda is driven by the threat of international competition resulting from economic globalisation. Successful competition is seen to be dependent on innovation, and innovation is seen to be stirred by new, science- and knowledge-based sectors such as life science [55]. Knowledge labour is needed to turn biological material into commercial and profitable products and, at the same time, is turned into an asset through intellectual property rights (IPRs). Due to the latter, the bioeconomy is seen to be underpinned by a rentier regime in which financial assets 
are more important than revenues from the sale of bio-based commodities [65]. The criticism is that the intensified commodification of biological matter [55,63] and of knowledge [66] is a key feature of bioeconomy strategies. These observations and criticisms relate primarily to the biotechnology-centred vision but also apply to the transformation-centred vision, because the relevant elements of the former vision fostering neoliberal economics are maintained.

\subsection{Definitions of Bioeconomy and Resulting Monitoring Approaches}

A clear distinction can be made between two approaches in the strategies to defining bioeconomy. These two types of definition are related to specific approaches to estimating the economic importance of the bioeconomy. An understanding of bioeconomy in a narrower sense tends to limit the economic assessment to the biotechnology industry or the emerging bio-based industry, for which economic data are still very difficult to obtain. Here, the common approaches are questionnaire surveys of companies or estimations based on corporate reporting and assessments of private consulting firms. Such estimations of the economic importance of the bioeconomy have been conducted for the EU bio-based industry [67], the US bio-based industry [68,69], the German biotech industry [70] and the US biotech industry [71,72].

In the context of a bioeconomy definition in a broader sense, assessment approaches include all sectors that produce, process or use biological resources, including traditional bioeconomy sectors such as agriculture and food industry. While statistical data for the primary production of biomass in agriculture, forestry and fishery are well established, the economic shares of downstream stages in biomass-based value chains are not readily available. A first attempt to assess the economic importance of the bioeconomy has been made for Germany, exploiting various official statistics and including all economic activities based on biomass [29]. Figures based on such a broad understanding have also been published for the EU [73-75]. Under this broad definition, the economic activities around food and wood still dominate the bioeconomy.

Varying specifications of system boundaries or bioeconomy definitions, lack of coherent cross-sectoral reporting systems, unreliability of international trade statistics, insufficient data on the share of bio-based inputs in production processes, and lack of transparency in biomass supply chains are the main obstacles for monitoring the economic development of the bioeconomy defined in a broader sense [29,76,77]. Overall, the measuring and monitoring challenges result from the cross-sectoral and dynamic innovations which the strategies intend to initiate. The development of specific codes for bio-based products in the Statistical Classification of Economic Activities in the European Community (NACE) or in the North American Industry Classification System (NAICS) in the USA is considered unfeasible [78]. The EU, Germany and The Netherlands are therefore undertaking modelling exercises to assess and monitor the bioeconomy by combining computable general equilibrium and partial equilibrium models and adding new specific modules [29,52,79-81].

\subsection{Transformation Perspective and Incremental Change Approach}

During their strategy developing processes, the EU and Germany have shifted from a biotechnology-centred vision to a transformation-centred vision. However, the approach of the bioeconomy strategies is still based on a technological innovation school of transformation thinking, recognising innovation in technologies as the central driver of societal change [82]. In particular, the transformation-centred vision holds the promise of fundamental changes in industrial resources and of solving global challenges. However, innovations are mostly sought in the technological trajectories of the last years and decades. Research topics change only incrementally. The dominant rationales and institutions are not questioned and the bioeconomy policies rely on a strong degree of trust in innovation and existing innovation systems. This also applies to other policy areas that are part of the strategies. For example, the European and German agricultural policy is not really questioned. In the German National Policy Strategy, measures for sustainable development in agriculture are restricted to the implementation of decisions already made on the Common 
Agricultural Policy, the National Action Plan for Sustainable Use of Plant Protection Products and so on [24] (p. 36). This is in line with the observation that in the transformation debate, radical problem diagnosis and promises of far-reaching change are combined with a rather incremental understanding of the processes and steps of societal change required to cope with the problems [83].

\subsection{Broadening Portfolio of Research Topics and Competing Value Chains}

The strategies based on a broader understanding of the bioeconomy focus on three sectors of biomass use: biomass for food and feed, industrial bio-based products and bioenergy. There is no clear prioritisation of one of these sectors over another. In many cases, separate specific R\&D programmes are launched for each sector. In contrast, a value pyramid has been proposed in The Netherlands. According to this pyramid, biomass is most valuable when used as pharmaceuticals or fine chemicals in the interest of health and lifestyle. Food and feed comes in second, and chemicals in third place. Using biomass as a source of energy is given the lowest priority [60,84]. The development of high-value, innovative materials and products is an objective in most of the strategies. However, the implementation of the strategies is predominantly focused on bio-based (bulk) chemicals or materials and bioenergy.

The vast majority of countries with bioeconomy policies support bioenergy and biofuels [85], the lowest level of the value pyramid. In the EU, the Renewable Energy Directive (RED) (Directive 2009/28/EC) [86] and the resulting regulations in the Member States give strong incentives for biofuel use and for electricity and heat production from biomass. Another example of such a policy approach is the Renewable Fuel Standard (RFS) [87] of the USA. In contrast, there is no direct support for bio-based materials, which yield higher value added, and policy support is limited to R\&D. This has raised concerns of a "non-level playing field" [88] that systematically prevents the development and investment in higher value added applications, such as bio-based chemicals and materials, due to higher prices and difficult access to biomass [89-91]. However, first assessments show that the abolition of biofuel policies would only have a moderate lowering impact on world agricultural commodity prices and no or only limited growth effect on the industrial use of biomass $[80,92]$. This indicates that fossil fuel prices and production costs of competing petrochemicals, based on the well-established and long-time optimised mass production of the chemical industry, are main determinants for the development of bio-based chemicals and materials. Moreover, in some contributions to the debate, advanced biofuels are considered an essential part of the future energy supply and bioeconomy [93,94].

For the transformation of the current chemical industry to a bio-based industry, competing approaches are discussed [88,95]: a strategy of drop-in commodity chemicals can directly substitute fossil-based chemical building blocks, use existing value respectively production chains, tap potentially high market volumes and result in high GHG emission savings [85]. The drop-in strategy is also associated with a number of disadvantages, such as low biomass utilisation efficiency, infancy of cost-effective fractionation and conversion technologies, required large-scale production with high biomass input as well as long-term incentives due to the higher production costs compared to the substituted low-price petrochemicals [88,95]. As an alternative is proposed an emerging strategy that fosters new bio-based building blocks, new value chains and pathways, with new properties for special applications, better conversion efficiency and the possibility of achieving higher prices $[88,95]$. This alternative approach also implies same drawbacks, such as restricted market penetration, slower development of bio-based industries, and smaller contribution to changing the resource base and to mitigating GHG emissions.

For developing bio-based products, the biorefinery plays a central role in the bioeconomy strategies. However, the term biorefinery encompasses a number of competing concepts [96]:

- $\quad$ sugar and starch biorefinery;

- plant oil and algae lipid biorefinery;

- lignocellulose biorefinery;

- green fibre/green juice biorefinery; 
- $\quad$ synthesis gas biorefinery; and

- biogas biorefinery.

This represents a complicated research landscape. While some countries show some concentration on a specific biorefinery concept, such as the USA on lignocellulosic ethanol biorefinery, research and development of several biorefinery concepts is generally supported in parallel. The intention is to avoid locking industrial development paths into specific sectors or technologies due to the uncertainty of technological break-troughs and future economic feasibility. However, an economic assessment of different biorefinery concepts demonstrates disparities in the economic robustness [97]. In other words, an open approach is associated with a risk of misinvestment.

Some of the strategies intend to link the sectors using biomass by promoting coupled and cascading uses (see Table 4). There is no general consensus on the definition of cascading use in both the research literature and among EU policy documents [98]. The most common understanding is that cascading use of biomass takes place when a bio-based final product is used at least once more either for material use or energy production [99]. It is seen as a means to ensure that the growth of biomaterials sectors does not increase the overall demand for biomass beyond sustainable limits [89]. However, establishing and increasing cascading uses is a difficult task. On the one hand, cascading use is already well established in traditional wood and paper industries [100]. On the other hand, multiple barriers exist to realise cascading. These include technical barriers, such as cleaning of recovered waste wood; market barriers, such as the dependence on upstream products; and governance barriers, such as waste status of recovered wood [101].

\subsection{Technology Fix and Limitations in Biomass Availability}

All bioeconomy strategies are focused on the development of technologies. They invest great expectations for unlocking the productive potential of biological resources through innovation. Current sustainability problems of biomass production and use are mainly framed as an efficiency issue. Resource constraints of rising global biomass demand are expected to be alleviated by more efficient processes, whilst organic waste will become a new resource. Specifically, biorefineries are envisioned as a possibility for more efficient conversion of biomass-preferably non-food biomass and bio-waste-into valuable products, thus providing substitutes for fossil-based products and energy within the current infrastructure. This approach was characterised as a "techno-fix" [55,102].

However, more efficient production and conversion of biomass has its limitations. Besides efficiency gains, the amount of biomass resources not yet exploited therefore becomes a key factor for the growth of the bioeconomy. Many assessments of biomass potentials, originally conducted for bioenergy production, are available at the global (comparison of studies in [103-105]), European (comparison of studies in $[106,107]$ ) and national level (comparison of German studies in [108]), but the estimated potentials vary widely. Scenarios with sustainable production considerations and environmental conservation restrictions result in reduced potentials [109-111]. The lack of a harmonised methodological approach covering minimum requirements for assessing biomass potentials is seen as a hindrance to evaluating the chances of a bio-based economy [112]. However, due to the variety of applicable models [113], the number of driving forces and their open future change [114,115], the multifunctionality of land [116] and complex feedback mechanisms [117], forecast uncertainties in the context of future biomass potentials and potential land use conflicts cannot be eliminated.

In contrast to the biofuel and bioenergy sector, the biomass demand of a future bio-based chemical industry has rarely been assessed. The first assessments arrive at the optimistic conclusion that the EU can supply enough biomass for a shift towards bio-based chemicals [118-120]. The demand for biomass and land is considerably lower if, instead of a strategy of platform chemicals, a biorefinery strategy for directly producing functionalised chemicals is applied, making it possible to use all crop components [119].

The already high land footprint of agricultural products consumed in the EU is used as an argument against a notable expansion of biomass uses [121,122]. Currently, the EU's demand 
for agricultural goods requires the use of over $40 \%$ more agricultural land than is available within the EU [122], and the per capita cropland footprint of 0.29 ha is well above the globally available cropland per capita [121]. For the future, a decrease of the EU's land footprint is advocated to ensure equitable land use among global citizens and within planetary boundaries. An opposite proposal is to generally encourage biofuel production and biomass for bioenergy in the tropical south for consumption in the temperate north, based on sustainability certification and opening of markets. The proposal is justified by available land reserves, higher productivity and beneficial impacts [123]. This would ultimately increase the external land footprint of industrialised countries. More generally, it is argued that opportunities for positive synergies between bioenergy and food production should be explored [124].

The bioeconomy strategies promote the use of organic wastes and residues in order to prevent negative impacts on food supply and land use. Organic wastes and residues are composed of primary residues from agriculture (e.g., straw and livestock manure) and forestry (e.g., logging and forest residues), secondary residues from food processing, wood industry and other industrial activities, and tertiary residues or wastes at the end of consumption such as municipal waste [104,125]. Biomass potentials from wastes and residues are in some cases included in overall assessments of biomass potentials $[103,104,107]$. However, most of the secondary and tertiary residues and wastes are already used [88]. A specific and detailed assessment of biogenic by-products, residues and wastes for Germany shows that almost all untapped potential lies in cereal straw, livestock manure and logging residues $[125,126]$. Two problems are associated with these categories of biomass residues: On the one hand, the removal of crop residues (e.g., straw) can decrease soil organic carbon and induce additional $\mathrm{CO}_{2}$ emissions [127]. There is no general agreement on the acceptable extent of sustainable extraction of agricultural and forestry residues, and a wide range of availability factors are applied in the respective studies [107]. On the other hand, the lack of appropriate supply chains for lignocellulosic feedstock is identified as a main barrier to the establishment of biorefineries [128]. Technical problems and/or cost of harvesting, transport, storage and pre-treatment are crucial upstream problems. In addition, there are no real markets for lignocellulosic residues, and the establishment of supply chains is difficult and costly [129].

The development and application of sustainability assessments and certification schemes are a key implementation approach of the bioeconomy strategies. In recent years, a large number of sustainability standards and certification schemes have been introduced, including mandatory and mostly voluntary certifications from companies, organisations and multi-stakeholder initiatives. Such schemes include feedstock and supply chains for bioenergy, but also for food/feed and biomaterials [130,131]. Sustainability criteria, indicators and evaluations differ depending on the goals, the context and the values of stakeholders [132], and there are on-going scientific and stakeholder debates about adequate sustainability criteria. Certification schemes are developed largely without coordination among the organisations involved and are incompatible in many aspects [76]. Socio-economic aspects of sustainability are not so well integrated, and certification has most potential to influence direct, local impacts [130]. Supranational sustainability schemes face challenges due to different national and local regulations and understandings as well as difficulties in establishing efficient monitoring and auditing systems [133]. In addition, significant shortcomings of European biofuel schemes regarding the impacts of intensive agriculture in industrialised countries such as Germany on agrobiodiversity and soil fertility are criticised [134].

Voluntary initiatives have gained a considerable market share, but it is considered unlikely that these alone will be able to further expand the sustainable market share and the desired sustainability effects [135]. Mandatory global sustainability certification for all kinds of biomass is considered desirable and a long-term goal [105] (pp. 250-252), [136]. Without such a general certification, existing specific schemes cannot cover systemic effects such as indirect land use change (ILUC). ILUC caused by biofuels has attracted considerable attention in the EU. However, ILUC effects can only be assessed based on models, and the assessments come to variating results. The introduction of ILUC factors 
in the EU regulation is discussed controversially [137]. In the case of forest bioenergy systems, it is questioned whether existing certification schemes are sufficient to counter already established public doubts that forest bioenergy can contribute to sustainable development [138].

Finally, the technological focus of the bioeconomy strategies entails that approaches to changing consumer behaviour and reducing the demand for bio-based products are addressed only marginally, if at all. Consequently, critics call for a stronger orientation of the bioeconomy towards sufficiency, longevity and circular economic processes [57]. Changes in consumption patterns are of particular relevance in the food and feed sector due their high share in total biomass demand: $72 \%$ of global biomass demand [139], 59\% of EU biomass demand [74], and 50\% of German biomass inputs in the manufacturing sector [29]. The discussion focuses on two points: reduction of food losses $[140,141]$ and changed diets with reduced consumption of animal products $[142,143]$.

\subsection{Contested Bioeconomy Visions}

Besides the two identified visions of the official bioeconomy strategies, an alternative vision has emerged from the scientific and societal debates about the bioeconomy. This alternative vision is called agroecology vision [54,144-146], alternative agriculture vision [147], bio-ecology vision [148], eco-economy vision [149] or socio-ecological approach [150] and is formulated with slight variations. The alternative vision has not only been developed in criticism of official bioeconomy strategies but also as a fundamental alternative to the currently dominant model of industrialised agriculture or agro-industrial regime, respectively. The differences to the visions of the official strategies are much stronger than differences among the two strategy visions (Table 6).

The agroecology vision is based on the diagnosis that profit-driven agro-industrial systems make farmers dependent on external inputs, undermine their knowledge and distance consumers from agricultural producers [146]. Instead of biotechnology and/or conversion technologies for new value chains, the technical focus is on agroecological techniques and methods such as increasing plant genetic diversity, improving nutrient recycling, enhancing biodiversity and improving health of soils, crops and livestock [54]. The aim is to minimise the need for external inputs and to rely on ecological interactions [151]. It is not unified land use for multipurpose biomass, also discussed under the term flex crops [152], that is being sought but multipurpose land use, also named multifunctionality of land [147]. Farmers are seen not only as commodity producers but also as providers of quality food and managers of the ecosystem. Therewith, the vision calls for a public goods-oriented bioeconomy [153]. 
Table 6. Comparison of bioeconomy strategy visions with the alternative vision.

\begin{tabular}{|c|c|c|c|}
\hline \multirow{2}{*}{ Issue } & \multicolumn{2}{|c|}{ Visions of Bioeconomy Strategies } & \multirow{2}{*}{$\begin{array}{c}\text { Alternative Vision } \\
\text { Ecology-Centred }\end{array}$} \\
\hline & Biotechnology-Centred & Transformation-Centred & \\
\hline Problem diagnosis & $\begin{array}{l}\text { Untapped potentials of biotechnology for economic growth; } \\
\text { Radical innovations }\end{array}$ & $\begin{array}{l}\text { Inefficiencies of farming practices, processing } \\
\text { methods and outputs; } \\
\text { Competition for techno-scientific advances }\end{array}$ & $\begin{array}{l}\text { Intensive, agro-industrial systems disrupting resource cycles, } \\
\text { making farmers dependent on external inputs, undermining } \\
\text { their knowledge and distancing consumers from } \\
\text { agri-production knowledge }\end{array}$ \\
\hline Technological focus & Biotechnology and genetic engineering & $\begin{array}{l}\text { Interdisciplinary, process-oriented development of } \\
\text { technologies for value chains }\end{array}$ & $\begin{array}{l}\text { Agroecological techniques and methods for sustainable use } \\
\text { of scarce natural resources }\end{array}$ \\
\hline \multirow[t]{2}{*}{ Knowledge focus } & $\begin{array}{l}\text { Knowledge from life science; } \\
\text { Capital-intensive knowledge production; }\end{array}$ & $\begin{array}{l}\text { Scientific knowledge for intelligent } \\
\text { production systems; }\end{array}$ & $\begin{array}{l}\text { Farmers' collective, experimental knowledge; } \\
\text { Scientific knowledge on agroecology; }\end{array}$ \\
\hline & Privatisable knowledge & Public-private partnerships & $\begin{array}{l}\text { Open source exchange of information and biological } \\
\text { materials }\end{array}$ \\
\hline \multirow{3}{*}{ Economic focus } & Capitalising on biotechnology; & Capitalising on bio-resources; & Capitalising on ecosystems; \\
\hline & $\begin{array}{l}\text { Application of biotechnology in various sectors; } \\
\text { Proprietary knowledge (e.g., patents); }\end{array}$ & $\begin{array}{c}\text { Conversion of biomass into new products via new } \\
\text { value chains; } \\
\text { Minimising organic waste production and } \\
\text { cascading use; }\end{array}$ & Emphasis on quality of food and food culture; \\
\hline & International competitiveness & International competitiveness & $\begin{array}{l}\text { Provision of public goods such as biodiversity, landscapes, } \\
\text { rural development }\end{array}$ \\
\hline Sustainability framing & Economic growth and claimed inherent sustainability & Economic growth and weak sustainability & Integrated, strong sustainability \\
\hline \multirow{2}{*}{ Spatial focus } & Globalised economy; & $\begin{array}{l}\text { Linking agriculture with industrial and } \\
\text { energy production; }\end{array}$ & Relocalising agro-food-energy production and consumption; \\
\hline & Limited number of leading innovation regions & $\begin{array}{l}\text { National to global value chains; } \\
\text { Rural regions development }\end{array}$ & $\begin{array}{l}\text { Place-based local/regional networks of value chains; } \\
\text { Territorial identities-terroir }\end{array}$ \\
\hline Land use understanding & - & Land use for multipurpose biomass-flex crops & Multipurpose land use-multifunctionality of land \\
\hline Agricultural production approach & Genetically modified crops & $\begin{array}{l}\text { Sustainable intensification with higher yields, more } \\
\text { efficient input use; } \\
\text { Science- and data-based (external) } \\
\text { management systems }\end{array}$ & $\begin{array}{l}\text { Agroecological production with closed loop nutrient and } \\
\text { energy cycles, enhanced soil fertility, high diversity and } \\
\text { biocontrol agents; } \\
\text { Minimising external inputs }\end{array}$ \\
\hline Product focus & Industrial products, biofuels, health products & Industrial products, bioenergy & Food products \\
\hline \multirow[t]{2}{*}{ Product quality approach } & $\begin{array}{l}\text { New qualities through biological research and emerging } \\
\text { technologies such as synthetic biology, proteomics and } \\
\text { bioinformatics }\end{array}$ & $\begin{array}{l}\text { Compositional qualities of biomass: identified, } \\
\text { quantified, standardised, extracted, decomposed } \\
\text { and recomposed components for market value; }\end{array}$ & $\begin{array}{l}\text { Comprehensive qualities of biomass: characterised by } \\
\text { cultivation methods, cultural value and/or } \\
\text { territorial identity; }\end{array}$ \\
\hline & & Sustainability certification & Food certification schemes (e.g., organic certification, $\mathrm{PGI}^{1}$ ) \\
\hline Up-stream resource utilisation approach & - & $\begin{array}{l}\text { More efficient use of biomass resources via new } \\
\text { conversion technologies and multiple products }\end{array}$ & $\begin{array}{l}\text { Reduced biomass resource demand via circular economy and } \\
\text { social innovation (e.g., sustainable consumption) }\end{array}$ \\
\hline
\end{tabular}

${ }^{1}$ PGI, Protected Geographical Indication; Source: Own compilation based on [54,144-149,153]. 
In the alternative, ecology-centred vision, knowledge production is based on farmer's knowledge and knowledge networks integrating scientific knowledge on agroecology [145] as well as open source exchange of information and biological materials [54]. The importance of local knowledge for enhancing local capabilities is highlighted [153]. According to the vision, agricultural residues and waste should be converted into bioenergy in on-farm, small-scale units [54,147]. However, most importantly, shorter food supply chains, relocation of food production and consumption and place-based local and regional networks of value chains are promoted. High-quality products with territorial identity are expected to provide opportunities for rural growth $[145,148,149]$. Qualities of biomass are conceptualised in a comprehensive way, depending on cultivation methods, tradition and terroir. In addition, social innovations are addressed to reduce biomass resource demand.

Overall, there is a strong asymmetry in the societal debates around bioeconomy visions: the alternative vision places far-reaching changes in agriculture and food production at its heart, whereas visions of official bioeconomy strategies imply a continuation of the current trajectory for these sectors. Vice versa, official strategy visions focus on new value chains for new bio-based industrial products and bioenergy while the alternative vision ignores the sector of bio-based chemicals and products.

Bioeconomy in the sense of the official strategies and agroecology are regarded as competing and contesting visions with rival stakeholder networks [145], with the former dominating research and innovation policy and being supported by powerful stakeholders. However, ecology-centred approaches are not generally excluded from research agendas and have gained some influence [54,146]. Some research topics and activities of the bioeconomy strategies incorporate elements of the agroecological approach, even the biotechnology-centred US Bioeconomy Blueprint, which includes research on organic agriculture [28] (pp. 20-21). However, these elements are still of minor importance and are constrained by limited financial resources.

\section{Conclusions}

Bioeconomy strategies conceptualise the intended future development as without alternative and their aims as more or less reachable. However, the discussion of the bioeconomy strategies has revealed a number of obstacles and uncertainties, conflicting interests within the bioeconomy and contested visions. In conclusion, five major stumbling blocks to the intended development of the bioeconomy can be identified.

First, there is a risk of disappointment. Both the biotechnology-centred vision and the transformation-centred vision have far-reaching expectations of, for example, radical innovations, transformation of the industrial resource base and strong economic growth effects. However, challenges such as the acquisition and transport of biomass, difficult conversion due to variable quality within and among different types of biomass, and competition of the sophisticated, integrated and long-time structure of the oil-based industry will hinder the transformation and slow down the development of new bioeconomy applications. For example, the emerging strategy proposes the creation of new value chains and new products for emerging markets instead of drop-in platform chemicals [88]. However, the recommended approach is associated with lower production volumes and would enable only a slow transition to a bio-based economy due to its incremental nature. Ambitious transformation goals would be brought back down to earth, and this might have an impact on political support and research funding of the bioeconomy. On the other hand, the non-realisation of the high ambitions also means avoidance of risk. More generally, there is a large discrepancy between the time it takes to develop new technologies and the perishability of expectations. Such a divergence of expectations would not be the first in the history of renewable resources policy [154]. Probable disappointments would not lead to the abolition of bioeconomy research, policy and economic activities but to a normalisation and refocusing of activities.

Second, the bioeconomy is not the only way to renewable carbon supply for the chemical industry and renewable energy systems. There are several non-bio-based alternatives with different 
pathways of carbon recycling and carbon capture from combustion or atmospheric $\mathrm{CO}_{2}$ which will further developed in the future [155]. In the context of the transformation to a renewable energy system, bioenergy options compete with numerous alternative renewables and are dependent on the future energy system arrangements. Consequently, the development of the bioeconomy desired in the strategies could be restricted in the future, depending on the technological progress of alternatives, the momentum of alternative narratives and the setting of political framing conditions.

Third, continued conflicts between different sectors of the bioeconomy and their use of biomass for food, material and energy production can be expected. For example, some strategies postulate a "food first" approach, but the operationalisation of this guiding principle remains unclear. Moreover, the strategies focus on research and innovation for material and energy uses of biomass, pursued in parallel. As long as no high taxes on fossil resources or high charges on climate gas emissions have been introduced, many new material and energetic uses of biomass will not be competitive and will continue to depend on political decisions about support and framework conditions. In the past, political support was unstable and changed within short periods of time, as for example shown for the German biofuel policy [156]. Probably, the definition of level playing field and decisions on what biomass uses to support will remain contested. Some strategies aim at better policy coordination, for example by inter-ministerial working groups, in order to achieve a coherent policy framework for the bioeconomy. However, crossovers between bioeconomy sectors and cross-sectoral policies are still missing [11], and coordination of policies across government ministries remains a challenge [18]. In addition, coordination does not protect against short-term policy shifts. In conclusion, there is susceptibility to a seesaw in the concrete arrangement of support policies, and investments are faced with high vulnerability.

Fourth, societal conflicts about the bioeconomy will only become apparent with a broader success of new bioeconomy value chains. The biofuel debates of the past indicate that opposition and societal debate will not begin until there is a noticeable increase in the production of new bio-based products and/or bioenergy production with a corresponding biomass demand. While food crops for energetic or material use, such as cereals, oilseeds or sugar cane, compete directly with food on the consumption side, the production of feedstock crops without possible use as food competes also for scarce resources, especially land [114]. As discussed for biofuels, sustainability challenges and controversies of first generation biofuels could be potentially relevant for second generation biofuels [157], and this could also apply to the aspired transformation towards a bio-based industry. It remains uncertain whether efficiency gains, cascading use, residue use and sustainability certification will be sufficient to avoid new conflicts. In addition, potential conflicts depend on future spatial arrangements and assessment of global biomass commodity chains [158]. Finally, events not directly connected with the activities in the framework of the bioeconomy strategies, such as the food crisis in $2007 / 2008$, could in the future trigger new opposition.

Fifths, bioeconomy strategies do not reflect the on-going societal debates on agriculture and food. However, biomass produced in agriculture is subject to on-going debates about the future of agriculture [147]. These debates have led to an alternative, ecology-centred vision, based on a fundamental critique of the current dominant model of industrialised agriculture. The alternative vision places far-reaching changes in agriculture and food production at its heart whereas visions of official bioeconomy strategies imply a continuation of the current trajectory for these sectors. The official bioeconomy strategies are thus challenged by the alternative vision. Ignoring the debates on agriculture and food could have the potential to compromise the acceptance of bioeconomy.

Early recognition, scientific evaluation, societal discussion and adequate consideration of these stumbling blocks are important prerequisites for a successful bioeconomy policy and a thriving development of the bioeconomy.

Acknowledgments: Part of the work was carried out within the framework of the research programme "Technology, Innovation and Society" of the Helmholtz Association and under the project "Bioeconomy in Baden-Württemberg", financed by the Ministry of Science, Research and the Arts of Baden-Württemberg 
as part of the Bioeconomy Research Programme Baden-Württemberg. The author thanks Alexandra Pehle for a first compilation of key elements of the bioeconomy strategies. Deutsche Forschungsgemeinschaft and Open Access Publishing Fund of Karlsruhe Institute of Technology are acknowledged for support.

Conflicts of Interest: The author declares no conflict of interest.

\section{References}

1. Georgescu-Roegen, N. The Entropy Law and the Economic Process; Harvard University Press: Cambridge, MA, USA, 1971.

2. Bonaiuti, M. Bioeconomics. In Degrowth. A Vocabulary for a New Era; D'Alisa, G., Demaria, F., Kallis, G., Eds.; Rourledge: Abingdon, UK; New York, NY, USA, 2014; pp. 25-28.

3. Enriquez, J. Genomics and the World's Economy. Science 1998, 281, 925-926. [CrossRef] [PubMed]

4. National Research Council (NRC). A New Biology for the 21st Century; The National Academic Press: Washington, DC, USA, 2009; Available online: http://www.nap.edu/catalog/12764/a-new-biology-fo r-the-21st-century (accessed on 24 May 2017).

5. Swinnen, J.; Riera, O. The global bio-economy. Agric. Econ. 2013, 44, 1-5. [CrossRef]

6. Von Braun, J. Bioeconomy and sustainable development—Dimensions. Rural 2014, 21, 6-9.

7. German Bioeconomy Council. Bioeconomy Policies around the World. Available online: http://www.bioo ekonomierat.de/biooekonomie/international/ (accessed on 24 May 2017).

8. Langeveld, J.W.A. Results of the JRC-SCAR Bioeconomy Survey; Biomass Research: Wageningen, The Netherlands, 2015; Available online: https://www.scar-swg-sbgb.eu/lw_resource/datapool/_items/item_24/survey_bi oeconomy_report1501_full_text.pdf (accessed on 24 May 2017).

9. Dieckhoff, P.; El-Cichakli, B.; Patermann, C. Bioeconomy Policy. Synopsis and Analysis of Strategies in the G7; A Report from the German Bioeconomy Council; Office of the Bioeconomy Council: Berlin, Germany, 2015; Available online: http://biooekonomierat.de/fileadmin/Publikationen/berichte/BOER_Laenderstudie_1 _pdf (accessed on 24 May 2017).

10. Fund, C.; El-Chichakli, B.; Dieckhoff, P. Bioeconomy Policy (Part II). Synopsis of National Strategies around the World; A Report from the German Bioeconomy Council; Office of the Bioeconomy Council: Berlin, Germany, 2015; Available online: http://biooekonomierat.de/fileadmin/Publikationen/berichte/Bioecono my-Policy_Part-II.pdf (accessed on 24 May 2017).

11. European Commission. Where Next for the European Bioeconomy? The Latest Thinking from the European Bioeconomy Panel and the Standing Committee on Agricultural Research Strategic Working Group (SCAR); European Commission: Brussels, Belgium, 2014. Available online: http:/ /ec.europa.eu/research/bioecono my/pdf/where-next-for-european-bioeconomy-report-0809102014_en.pdf (accessed on 24 May 2017).

12. Staffas, L.; Gustavsson, M.; McCormick, K. Strategies and Policies for the Bioeconomy and Bio-Based Economy: An Analysis of Official National Approaches. Sustainability 2013, 5, 2751-2769. [CrossRef]

13. De Besi, M.; McCormick, K. Towards a Bioeconomy in Europe: National, Regional and Industrial Strategies. Sustainability 2015, 7, 10461-10478. [CrossRef]

14. Overbeek, G.; de Bakker, E.; Beekman, V.; Davies, S.; Kresiewa, Z.; Delbrück, S.; Ribeiro, B.; Soyanov, M.; Vale, M. Review of Bioeconomy Strategies at Regional and National Level. BioSTEP Project, Report D2.3. 2016. Available online: http://bio-step.eu/fileadmin/BioSTEP/Bio_documents/BioSTEP_D2.3_Review _of_strategies.pdf (accessed on 24 May 2017).

15. Reime, M.; Røste, R.; Almasi, A.; Coenen, L. The Circular Bioeconomy in Scandinavia. Report of the SusValueWaste Project. 2016. Available online: http://www.susvaluewaste.no/wp-content/uploads/20 16/06/SusValueWaste-2016-The-circular-bioeconomy-in-Scandinavia.pdf (accessed on 24 May 2017).

16. Grin, J.; Grunwald, A. (Eds.) Vision Assessment: Shaping Technology in 21st Century; Wissenschaftsethik und Technikfolgenbeurteilung Band 4; Springer: Berlin/Heidelberg, Germany, 2000.

17. Grunwald, A. Technikzukünfte als Medium von Zukunftsdebatten und Technikgestaltung; Karlsruher Studien Technik und Kultur Band 6; KIT Scientific Publishing: Karlsruhe, Germany, 2012; Available online: http:/ / digbib.ubka.uni-karlsruhe.de/volltexte/1000030441 (accessed on 24 May 2017). 
18. Organisation of Economic Co-Operation and Development (OECD). The Bioeconomy to 2030. Designing a Policy Agenda. Main Findings and Policy Conclusions; OECD: Paris, France, 2009; Available online: http:/ / www.oecd.org/futures/long-termtechnologicalsocietalchallenges/thebioeconomyt o2030designingapolicyagenda.htm (accessed on 24 May 2017).

19. European Commission. Innovating for Sustainable Growth: A Bioeconomy for Europe. Communication from the Commission to the European Parliament, the Council, the European Economic and Social Committee and the Committee of the Regions. 2012. Available online: http:/ / ec.europa.eu/research/bioeconomy/pdf /official-strategy_en.pdf (accessed on 24 May 2017).

20. European Commission. Innovating for Sustainable Growth: A Bioeconomy for Europe. Commission Staff Working Document. 2012. Available online: https:/ /ec.europa.eu/research/bioeconomy/pdf/201202_co mmision_staff_working.pdf (accessed on 24 May 2017).

21. Bioökonomierat (German Bio-economy Research and Technology Council). Combine Disciplines, Improve Parameters, Seek out International Partnerships. First Recommendations for Research into the Bio-Economy in Germany; Forschungs- und Technologierat Bioökonomie: Berlin, Germany, 2009; Available online: http://biooekonomierat.de/fileadmin/Publikationen/Englisch/BOER_recommandation01.pdf (accessed on 24 May 2017).

22. Bioökonomierat (German Bio-Economy Research and Technology Council). Bio-Economy Innovation. Bio-Economy Council Report 2010; Forschungs- und Technologierat Bioökonomie: Berlin, Germany, 2011; Available online: http:/ / biooekonomierat.de/fileadmin/Publikationen/Englisch/bioeconomy_council_r eport_2010.pdf (accessed on 24 May 2017).

23. BMBF (German Federal Ministry for Education and Research). Nationale Forschungsstrategie Bioökonomie 2030 (National Research Strategy Bioeconomy 2030); Unser Weg zu einer biobasierten Wirtschaft: Berlin, Germany, 2010; Available online: https://www.bmbf.de/pub/Nationale_Forschungsstrategie_Biooekonomie_2030. pdf (accessed on 24 May 2017).

24. BMEL (German Federal Ministry for Food and Agriculture). National Policy Strategy on Bioeconomy; BMEL: Berlin, Germany, 2014. Available online: http:/ /www.bmel.de/SharedDocs/Downloads/EN/Publications /NatPolicyStrategyBioeconomy.pdf?blob=publicationFile (accessed on 24 May 2017).

25. MIWF NRW (Ministry for Innovation, Science and Research North Rhine-Westphalia). Eckpunkte einer Bioökonomiestrategie für Nordrhein-Westfalen (Basic Points of a Bioeconomy Strategy for North Rhine-Westphalia); MIWF NRW: Düsseldorf, Germany; Available online: http:/ /www.wissenschaft.nrw.de/fileadmin/Medie n/Dokumente/Forschung/Fortschritt/Biooekonomiestrategie_NRW.pdf (accessed on 24 May 2017).

26. MWK BW (Ministry of Science, Research and Art Baden-Württemberg). Bioökonomie im System Aufstellen. Konzept für Eine Baden-Württembergische Forschungsstrategie "Bioökonomie" (Concept for the Implementation of a Research Strategy on the Bioeconomy in Baden-Württemberg); MWK BW: Stuttgart, Germany, 2013; Available online: https://mwk.baden-wuerttemberg.de/fileadmin/redaktion/m-mwk/intern/dateien/pdf/Fors chung/Konzept_Forschungsstrategie_Biooekonomie.pdf (accessed on 24 May 2017).

27. FORMAS (The Swedish Research Council for Environment, Agricultural Science and Spatial Planning). Swedish Research and Innovation. Strategy for a Bio-Based Econom; FORMAS: Stockholm, Sweden, 2012; Available online: http://www.formas.se/PageFiles/5074/Strategy_Biobased_Ekonomy_hela.pdf (accessed on 24 May 2017).

28. The White House. National Bioeconomy Blueprint; The White House: Washington, DC, USA, 2012. Available online: https:/ / obamawhitehouse.archives.gov/sites/default/files/microsites/ostp/national_bioecono my_blueprint_april_2012.pdf (accessed on 24 May 2017).

29. Efken, J.; Dirksmeyer, W.; Kreins, P.; Knecht, M. Measuring the importance of bioeconomy in Germany: Concept and illustration. NJAS Wagening J. Life Sci. 2016, 77, 9-17. [CrossRef]

30. Lösch, A.; Schneider, C. Transforming power/knowledge apparatuses: the smart grid in the German energy transition. Innov. Euro. J. Soc. Sci. Res. 2016, 29, 262-284. [CrossRef]

31. Brown, N.; Rappert, B.; Webster, A. (Eds.) Contested Futures. A Sociology of Prospective Techno-Science; Ashgate: Aldershot, UK, 2000.

32. McCormick, K.; Kautto, N. The Bioeconomy in Europe: An Overview. Sustainability 2013, 5, $2589-2608$. [CrossRef]

33. Aguilar, A.; Magnien, E.; Thomas, D. Thirty years of European biotechnology programmes: From biomolecular engineering to the bioeconomy. New Biotechnol. 2013, 30, 410-425. [CrossRef] [PubMed] 
34. European Commission. New Perspectives on the Knowledge-Based Bio-Economy; Conference Report; European Commission: Brussels, Belgium, 2005; Available online: http:/ /edz.bib.uni-mannheim.de/daten/ edz-bra/gdre/05/kbbe_conferencereport.pdf (accessed on 24 May 2017).

35. European Council. Lisbon Strategy. Presidency Conclusions Lisbon European Council 23 and 24 March 2000. Available online: http:/ / www.europarl.europa.eu/summits/lis1_en.htm (accessed on 24 May 2017).

36. German Presidency. En Route to the Knowledge-Based Bio-Economy. Cologne Paper. 2007. Available online: https:/ /dechema.de/dechema_media/Cologne_Paper-p-20000945.pdf (accessed on 24 May 2017).

37. Belgian Presidency. The Knowledge-Based Bio-Economy (KBBE) in Europe: Achievements and Challenges; Belgian Presidency: Brussels, Belgium, 2010; Available online: http://www.mercadosbiotecnologicos.com/docume nts/the_knowledge_based_bioeconomy_kbbe_in_europe.pdf (accessed on 24 May 2017).

38. BECOTEPS (Bio-Economy Technology Platforms). The European Bioeconomy in 2030. Delivering Sustainable Growth by Addressing the Grand Societal Challenges; BECOTEPS: Brussels, Belgium, 2011; Available online: http:/ / www.epsoweb.org/ file/560 (accessed on 24 May 2017).

39. European Commission. Europe 2020. A Strategy for Smart, Sustainable and Inclusive Growth; COM(2010) 2020; European Commission: Brussels, Belgium, 2010; Available online: http:/ / eur-lex.europa.eu/LexUriServ/L exUriServ.do?uri=COM:2010:2020:FIN:EN:PDF (accessed on 24 May 2017).

40. Scarlat, N.; Dallemand, J.-F.; Monforti-Ferrario, F.; Nita, V. The role of biomass and bioenergy in a future bioeconomy: Policies and facts. Environ. Dev. 2015, 15, 3-34. [CrossRef]

41. European Commission. Bio-Based Economy for Europe: State of Play and Future Potential-Part 1; Report on the European Commission's Public On-Line Consultation; European Commission: Brussels, Belgium, 2011; Available online: http:/ / ec.europa.eu/research/consultations/bioeconomy/bio-based-economy-for-eur ope-part1.pdf (accessed on 24 May 2017).

42. European Commission. Bio-Based Economy in Europe: State of Play and Future Potential-Part 2; Summary of the Position Papers Received in Response of the European Commission's Public On-Line Consultation; European Commission: Brussels, Belgium, 2011; Available online: http:/ /ec.europa.eu/research/consultati ons/bioeconomy/bio-based-economy-for-europe-part2.pdf (accessed on 24 May 2017).

43. Horizon 2020. The EU Framework Programme for Research and Innovation. Available online: https:/ / ec.europa.eu/programmes/horizon2020/ (accessed on 24 May 2017).

44. BMBF (German Federal Ministry for Education and Research). Wegweiser Bioökonomie. Forschung für Biobasiertes und Nachhaltiges Wirtschaftswachstum; BMBF: Berlin, Germany, 2014. Available online: https:/ / www.bmbf.de/pub/Wegweiser_Biooekonomie.pdf (accessed on 24 May 2017).

45. BMBF (German Federal Ministry for Education and Research). The New High-Tech Strategy. Innovations for Germany; BMBF: Berlin, Germany, 2014. Available online: https:/ /www.bmbf.de/pub/HTS_Broschuere_e ng.pdf (accessed on 24 May 2017).

46. Capgemini Consulting. Roadmap zur Errichtung einer Knowledge-Based Bio-Economy. Nordrhein-Westfalen auf dem Weg in die Umsetzung; Ministerium für Innovation, Wissenschaft und Forschung des Landes Nordrhein-Westfalen: Düsseldorf, Germany, 2010; Available online: http:/ /www.wissenschaft.nrw.de/filea dmin/Medien/Dokumente/Forschung/Fortschritt/Biooekonomie-Studie.pdf (accessed on 24 May 2017).

47. MIWF NRW (Ministry for Innovation, Science and Research of North Rhine-Westphalia). Forschungsstrategie Fortschritt NRW. Forschung und Innovation für nachhaltige Entwicklung 2013-2020; MIWF NRW: Düsseldorf, Germany, 2013; Available online: http://www.wissenschaft.nrw.de/fileadmin/Medien/Dokumente/Fors chung/Fortschritt/Broschuere_Fortschritt_NRW.pdf (accessed on 24 May 2017).

48. Winther, T. Bioeconomy Strategies and Policies in the Baltic Sea Region Countries, State of Play. Working Paper No. 1 of the Baltic Sea Regional Bioeconomy Council. 2016. Available online: http:/ /bsrbioeconomy. net/resources/2016_docs/Working_Paper_1_\%20BSR_Council.pdf (accessed on 24 May 2017).

49. OPST (Office of Science and Technology Policy). Request for Information: Building a 21st Century Bioeconomy; OPST: Washington, DC, USA, 2011.

50. OPST (Office of Science and Technology Policy). National Bioeconomy Blueprint: Public Comment; OPST: Washington, DC, USA, 2011. Available online: https://obamawhitehouse.archives.gov/administration/eo p/ostp/library/bioeconomy (accessed on 24 May 2017).

51. Barben, D. Politische Ökonomie der Biotechnologie. Innovation und Gesellschaftlicher Wandel im Internationalen Vergleich; Campus Verlag: Frankfurt, Germany; New York, NY, USA, 2007. 
52. BMBF (German Federal Ministry for Education and Research). Bioökonomie als Gesellschaftlicher Wandel; Konzept zur Förderung sozial- und wirtschaftswissenschaftlicher Forschung für die Bioökonomie; BMBF: Berlin, Germany, 2014. Available online: https://www.bmbf.de/pub/Biooekonomie_als_gesellschaftlicher_ Wandel.pdf (accessed on 24 May 2017).

53. Pfau, S.F.; Hagens, J.E.; Dankbaar, B.; Smits, A.J.M. Visions of Sustainability in Bioeconomy Research. Sustainability 2014, 6, 1222-1249. [CrossRef]

54. Levidow, L.; Birch, K.; Papaioannou, T. EU agri-innovation policy: Two contending visions of the bio-economy. Crit. Policy Stud. 2012, 6, 40-65. [CrossRef]

55. Birch, K.; Levidow, L.; Papaioannou, T. Sustainable Capital? The Neoliberalization of Nature and Knowledge in the European "Knowledge-based Bio-economy". Sustainability 2010, 2, 2898-2918. [CrossRef]

56. Birch, K.; Levidow, L.; Papaioannou, T. Self-Fulfilling Prophecies of the European Knowledge-Based Bio-Economy: The Discursive Shaping of Institutional and Policy Frameworks in the Bio-Pharmaceuticals Sector. J. Knowl. Econ. 2014, 5, 1-18. [CrossRef]

57. Albrecht, S.; Gottschick, M.; Schorling, M.; Stirn, S. Bioökonomie am Scheideweg. Industrialisierung von Biomasse oder nachhaltige Produktion? GAIA 2012, 21, 33-37. [CrossRef]

58. Gottwald, F.-T. Irrweg Bioökonomie. Über die zunehmende Kommerzialisierung des Lebens. In Der kritische Agrarbericht 2015; AgrarBündnis, Ed.; ABL-Verlag: Konstanz/Hamm, Germany, 2015; pp. 259-264.

59. McCormick, K. The emerging bio-economy in Europe: Exploring the key governance challenges. In Proceedings of the World Renewable Energy Congress, Linköping, Sweden, 8-13 May 2011; pp. 2316-2322.

60. Bosman, R.; Rotmans, J. Benchmarking Finnish and Dutch Bioeconomy Transition Governance; Dutch Research Institute for Transitions (Drift): Rotterdam, The Netherlands, 2014. Available online: http:/ /www.syke.fi/do wnload/noname/\%7BD0EEFE22-B1A9-4AA6-85D4-24F065FD9719\%7D/112931 (accessed on 24 May 2017).

61. Sitjsema, S.J.; Onwezen, M.C.; Reinders, M.J.; Dagevos, H.; Partanen, A.; Meeusen, M. Consumer perception of bio-based products-An exploratory study in 5 European countries. NJAS Wagening. J. Life Sci. 2016, 77, 61-69.

62. European Commission. European Bioeconomy Panel. Profiles of Panel Members; European Commission, Directorate-General for Research and Innovation, Directorate E-Biotechnologies, Agriculture, Food: Brussels, Belgium, 2013; Available online: http:/ / ec.europa.eu/research/bioeconomy/pdf/european-bioe conomy-panel-list-17092013_en.pdf (accessed on 24 May 2017).

63. Birch, K. The Neoliberal Underpinning of the Bioeconomy: The Ideological Discourse and Practices of Economic Competitiveness. Genom. Soc. Policy 2006, 2, 1-15. [CrossRef]

64. Pülzl, H.; Kleinschmit, D.; Arts, B. Bioeconomy-An emerging meta-discourse affecting forest discourses? Scand. J. For. Res. 2014, 29, 386-393. [CrossRef]

65. Birch, K.; Tyfield, D. Theorizing the Bioeconomy: Biovalue, Biocapital, Bioeconomics or ... What? Sci. Technol. Hum. Values 2012, 38, 299-327. [CrossRef]

66. Goven, J.; Pavone, V. The Bioeconomy as Political Project: A Polanyian Analysis. Sci. Technol. Hum. Values 2015, 40, 302-337. [CrossRef]

67. Nattrass, L.; Biggs, C.; Bauen, A.; Parisi, C.; Rodríguez-Cerezo, E.; Gómez-Barbero, M. The EU Bio-Based Industry: Results from a Survey; JRC Technical Reports; EUR 27736 EN; Publications Office of the European Union: Luxembourg, 2016. [CrossRef]

68. Golden, J.S.; Handfield, R.B.; Daystar, J.; McConnell, T.E. An Economic Impact Analysis of the U.S. Biobased Products Industry: A Report to the Congress of the United States of America. A Joint Publication of the Duke Center for Sustainability \& Commerce and the Supply Chain Resource Cooperative at North Carolina State University. 2015. Available online: https://www.biopreferred.gov/BPResources/files/EconomicRep ort_6_12_2015.pdf (accessed on 24 May 2017).

69. Golden, J.S.; Handfield, R.; Daystar, J.; Morrison, B.; McConnell, E. An Economic Impact Analysis of the U.S. Biobased Products Industry. 2016. Available online: https://www.biopreferred.gov/BPResources/files/Bio basedProductsEconomicAnalysis2016.pdf (accessed on 24 May 2017).

70. BIOCOM. The German Biotechnology Sector, Facts \& Figures 2016; BIOCOM AG: Berlin, Germany, 2016; Available online: http://www.iwbio.de/fileadmin/Publikationen/IWBio-Publikationen/GermanBiotech Sector2016.pdf (accessed on 24 May 2017).

71. Carlson, R. Estimating the biotech sector's contribution to the US economy. Nat. Biotechnol. 2016, 34, $247-255$. [CrossRef] [PubMed] 
72. Morisson, C.; Lähteenmäki, R. Public biotech in 2014-The numbers. Nat. Biotechnol. 2015, 33, 703-709. [CrossRef] [PubMed]

73. Piotrowski, S.; Carus, M.; Carrez, D. European Bioeconomy in Figures; nova-Institute for Ecology and Innovation: Hürth, Germany, 2016; Available online: http://biconsortium.eu/sites/biconsortium.eu/ files/news-image/16-03-02-Bioeconomy-in-figures.pdf (accessed on 24 May 2017).

74. Ronzon, T.; Santini, F.; M'Barek, R. The Bioeconomy in the European Union in Numbers. Facts and Figures on Biomass, Turnover and Employment; European Commission, Joint Research Centre, Institute for Prospective Technological Studies: Seville, Spain, 2015; Available online: https://biobs.jrc.ec.europa.eu/sites/default/fil es/generated/files/documents/BioeconomyFactsheet_Final.pdf (accessed on 24 May 2017).

75. Benzing, T.; Mosquera, J. Measuring Bio-Based Raw Materials Use in the Chemical Industry; CEFIC (European Chemical Industry Council): Brussels, Belgium, 2014. Available online: https://biobs.jrc.ec.e uropa.eu/stakeholder/cefic-study-measuring-bio-based-raw-materials-use-chemical-industry (accessed on 24 May 2017).

76. Goh, C.S.; Junginger, M.; Faaij, A. Monitoring sustainable biomass flows: General methodology development. Biofuels Bioprod. Bioref. 2014, 8, 83-102. [CrossRef]

77. Vandermeulen, V.; Prins, W.; Nolte, S.; Van Huylenbroeck, G. How to measure the size of a bio-based economy: Evidence from Flanders. Biomass Bioenergy 2011, 35, 4368-4375. [CrossRef]

78. Parisi, C.; Ronzon, T. A Global View of Bio-Based Industries: Benchmarking and Monitoring Their Economic Importance and Future Developments; JRC Technical Reports; EUR 28376; Publications Office of the European Union: Luxembourg, 2016. [CrossRef]

79. SAT-BBE Consortium. Design of a Systems Analysis Tools Framework for a EU Bioeconomy Strategy; Report D 3.3. 2015. Available online: http://www3.lei.wur.nl/SATBBE_Publications/SAT-BBE\%20-\%20WP 3\%20-\%20Deliverable\%203.3_FINAL_May15.pdf (accessed on 24 May 2017).

80. Philippidis, G.; M'barek, R.; Ferrari, E. Drivers of the European Bioeconomy in Transition (BioEconomy2030)—An Exploratory, Model-Based Assessment; EUR 27563 EN; Institute for Prospective Technological Studies, Joint Research Centre: Seville, Spain, 2016; Available online: https:/ /biobs.jrc.ec.europa.eu/sites/default/files/generated/f iles/documents/drivers-of-the-eu-bioeconomy-in-transition.pdf (accessed on 24 May 2017). [CrossRef]

81. Van Meijl, H.; Tsiropoulos, I.; Bartelings, H.; van den Broek, M.; Hoefnagels, R.; Van Leeuwen, M.; Smeets, E.; Tabeau, A.; Faaij, A. Macroeconomic Outlook of Sustainable Energy and Biorenewables Innovations (MEV II); LEI Report 2016-001; Wageningen UR (University \& Research centre), LEI: Wageningen, The Netherlands, 2016; Available online: http:/ / edepot.wur.nl/370901 (accessed on 24 May 2017).

82. Schneidewind, U.; Augenstein, K. Three Schools of Transformation Thinking. The Impact of Ideas, Institutions and Technological Innovation on Transformation Processes. GAIA 2016, 25, 88-93. [CrossRef]

83. Brand, U. "Transformation" as a New Critical Orthodoxy. The Strategic Use of the Term "Transformation" Does Not Prevent Multiple Crises. GAIA 2016, 25, 23-27. [CrossRef]

84. Asveld, L.; van Est, R.; Stemerding, D. (Eds.) Getting to the Core of the Bio-Economy. A Perspective on the Sustainable Promise of Biomass; Rathenau Instituut: Den Haag, The Netherlands, 2011; Available online: https://www.rathenau.nl/en/publication/getting-core-bio-economy (accessed on 24 May 2017).

85. Philp, J. Balancing the bioeconomy: Supporting biofuels and bio-based materials in public policy. Energy Environ. Sci. 2015, 8, 3063-3068. [CrossRef]

86. Directive 2009/28/EC of the European Parliament and of the Council of 23 April 2009 on the Promotion of the Use of Energy from Renewable Sources and Amending and Subsequently Repealing Directives 2001/77/EC and 2003/30/EC. 2009. Available online: http:/ / eur-lex.europa.eu/legal-content/DE/ALL/? uri=CELEX\%3A32009L0028 (accessed on 24 May 2017).

87. EPA 2016. Renewable Fuel Standard Program: Standards for 2017 and Biomass-Based Diesel Volume for 2018. Federal Register 2016, 81, No. 238; pp. 89746-89804. Available online: https:/ /www.gpo.gov/fdsys / pkg/FR-2016-12-12/pdf/2016-28879.pdf (accessed on 24 May 2017).

88. Carus, M.; Raschka, A.; Iffland, K.; Dammer, L.; Essel, R.; Piotrowski, S. How to Shape the Next Level of the European Bio-Based Economy? Renewablematter 2016. Available online: http://www.renewablem atter.eu/art/170/How_to_Shape_The_Next_Level_of_The_European_BioBased_Economy (accessed on 24 May 2017).

89. Keegan, D.; Kretschmer, B.; Elbersen, B.; Panoutsou, C. Cascading use: A systematic approach to biomass beyond the energy sector. Biofuels Bioprod. Bioref. 2013, 7, 193-206. [CrossRef] 
90. Carus, M.; Dammer, L.; Essel, R. Options for Designing a New Political Framework of the European Bio-Based Economy; Nova Policy Paper 2014-10; Nova-Institut: Hürth, Germany, 2014; Available online: http:/ / bio-based.eu/downloads/options-designing-new-political-framework-european-bio-based-econ omy-nova-institutes-contribution-current-debate-2/ (accessed on 24 May 2017).

91. Dammer, L.; Bowyer, C.; Breitmayer, E.; Eder, A.; Nanni, S.; Allen, B.; Carus, M.; Essel, R. Mapping Study on Cascading Use of Wood Products. WWF Technical Report. 2016. Available online: http://mobil.wwf.de/fil eadmin/fm-wwf/Publikationen-PDF/WWF-Study_Cascading_Use_of_Wood_Products.pdf (accessed on 24 May 2017).

92. Araujo Enciso, S.R.; Fellmann, T.; Dominguez, I.P.; Santini, F. Aboshing biofuel policies: Possible impacts on agricultural price levels, price variability and global food security. Food Policy 2016, 61, 8-26. [CrossRef]

93. Caspeta, L.; Buijs, N.A.A.; Nielsen, J. The role of biofuels in the future energy supply. Energy Environ. Sci. 2013, 6, 1077-1082.

94. Fulton, L.M.; Lynd, L.R.; Körner, A.; Greene, N.; Tonachel, L.R. The need for biofuels as part of a low carbon energy future. Biofuels Bioprod. Bioref. 2015, 9, 476-483. [CrossRef]

95. Kovacs, B. (Ed.) Sustainable Agriculture, Forestry and Fisheries in the Bioeconomy-A Challenge for Europe; 4th SCAR Foresight Exercise; European Commission: Brussels, Belgium, 2015; Available online: https:/ / ec.europa.eu/research/scar/pdf/ki-01-15-295-enn.pdf (accessed on 24 May 2017).

96. Bundesregierung (The Federal Government). Roadmap Bioraffinerien; Bundesregierung: Berlin, Germany, 2012; Available online: http://www.bmel.de/SharedDocs/Downloads/Broschueren/RoadmapBioraffinerien.pdf (accessed on 24 May 2017).

97. Cheali, P.; John, A.; Posada, J.A.; Gernaey, K.V.; Sin, G. Economic risk analysis and critical comparison of optimal biorefinery concepts. Biofuels Bioprod. Bioref. 2016, 10, 435-445. [CrossRef]

98. Olsson, O.; Bruce, L.; Hektor, B.; Roos, A.; Guisson, R.; Lamers, P.; Hartley, D.; Ponitka, J.; Hildebrand, D.; Thrän, D. Cascading of Woody Biomass: Definitions, Policies and Effects on International Trade. Working Paper IEA Bioenergy Task 40. 2016. Available online: http:/ /task40.ieabioenergy.com/wp-content/uploads /2013/09/t40-cascading-2016.pdf (accessed on 24 May 2017).

99. Essel, R.; Breitmayer, E.; Carus, M.; Fehrenbach, H.; von Geibler, J.; Bienge, K.; Baur, F. Defining Cascading Use of Biomass. Discussion Paper. R\&D-Project "Increasing Resource Efficiency by Cascading Use of Biomass-From Theory to Practice". Available online: https://biomassekaskaden.de/wp-content/uploads /2014/04/14-03-14_Cascading_use_Discussionpaper.pdf (accessed on 24 May 2017).

100. Mantau 2012. Wood Flows in Europe. Available online: http://www.cepi.org/system/files/public/docume nts/publications/forest/2012/CEPIWoodFlowsinEurope2012.pdf (accessed on 24 May 2017).

101. Vis, M.; Mantau, U.; Allen, B. (Eds.) Study on the Optimised Cascading Use of Wood. No 394/PP/ENT/RCH/14/7689. Final Report. 2016. Available online: http://bookshop.europa.eu/e n/cascades-pbET0416305/ (accessed on 24 May 2017).

102. Levidow, L. Eco-efficient biorefineries: Techno-fix for resource constrains? Écon. Rural. 2015, 5, 349-350. [CrossRef]

103. Thrän, D.; Seidenberger, T.; Zeddies, J.; Offermann, R. Global biomass potentials-Resources, drivers and scenario results. Energy Sustain. Dev. 2010, 14, 200-205. [CrossRef]

104. Haberl, H.; Beringer, T.; Bhattacharya, S.C.; Erb, K.-H.; Hoogwijk, M. The global technical potential of bio-energy in 2050 considering constrains. Curr. Opin. Environ. Sustain. 2010, 2, 394-403. [CrossRef] [PubMed]

105. WBGU (German Advisory Council on Global Change). World in Transition: Future Bioenergy and Sustainable Land Use; WBGU: Berlin, Germany, 2011; Available online: http://www.wbgu.de/fileadmin/user_upload/wbgu.d e/templates/dateien/veroeffentlichungen/hauptgutachten/jg2008/wbgu_jg2008_en.pdf (accessed on 24 May 2017).

106. Haberl, H.; Erb, K.-H.; Lauk, C.; Plutzar, C. Menschliche Aneignung von Nettoprimärproduktion in Europa: Schlussfolgerungen für Bioenergiepotentiale (Human Appropriation of Net Primary Production in Europe: Conclusions with Respect to Bioenergy Potentials). In Bioenergy-Chances and Limits, Statement; Leopoldina (German National Academy of Sciences Leopoldina): Halle (Saale), Germany, 2012; pp. 102-118. Available online: https://www.leopoldina.org/uploads/tx_leopublication/201207_Stellungnahme_Bioe nergie_LAY_en_final_01.pdf (accessed on 24 May 2017).

107. Bentsen, N.S.; Felby, C. Biomass for energy in the European Union-A review of bioenergy resource assessments. Biotechnol. Biofuels 2012, 5, 25. [CrossRef] [PubMed] 
108. Meyer, R.; Grunwald, A.; Rösch, C.; Sauter, A. Chancen und Herausforderungen neuer Energiepflanzen, Basisanalysen (Opportunities and Challenges Facing New Energy Crops); TAB-Arbeitsbericht Nr. 121; TAB (Büro für Technikfolgen-Abschätzung beim Deutschen Bundestag): Berlin, Germany, 2007; Available online: http://www.tab-beim-bundestag.de/de/pdf/publikationen/berichte/TAB-Arbeitsber icht-ab121.pdf (accessed on 24 May 2017).

109. European Environmental Agency (EEA). How Much Bioenergy Can Europe Produce Without Harming the Environment? EEA Report 7/2006; EEA: Copenhagen, Denmark, 2006; Available online: http:/ /www.eea.europa.eu/publications/eea_report_2006_7 (accessed on 24 May 2017).

110. Fischer, G.; Prielera, S.; van Velthuizena, H.; Berndes, G.; Faaij, A.; Londo, M.; de Wit, M. Biofuel production potentials in Europe: Sustainable use of cultivated land and pastures, Part II: Land use scenarios. Biomass Bioenergy 2010, 34, 173-187. [CrossRef]

111. Haase, M.; Rösch, C.; Ketzer, D. GIS-based assessment of sustainable crop residue potentials in European regions. Biomass Bioenergy 2016, 86, 156-171. [CrossRef]

112. Hennig, C.; Brosowski, A.; Majer, S. Sustainable feedstock potential-A limitation for the bio-based economy? J. Clean. Prod. 2016, 123, 200-202. [CrossRef]

113. Wicke, B.; van der Hilst, F.; Daioglou, V.; Banse, M.; Beringer, T.; Gerssen-Gondelach, S.; Heijnen, S.; Karssenberg, D.; Laborde, D.; Lippe, M.; et al. Model collaboration for the improved assessment of biomass supply, demand, and impacts. GCB Bioenergy 2015, 7, 422-437. [CrossRef]

114. Dornburg, V.; van Vuuren, D.; van de Ven, G.; Langeveld, H.; Meeusen, M.; Banse, M.; van Oorschot, M.; Ros, J.; van den Born, G.J.; Aiking, H.; et al. Bioenergy revisited: Key factors in global potentials of bioenergy. Energy Environ. Sci. 2010, 3, 258-267. [CrossRef]

115. Lewandowski, I. Securing a sustainable biomass supply in a growing bioeconomy. Glob. Food Secur. 2015, 6, 34-42. [CrossRef]

116. Tomei, J.; Helliwell, R. Food versus fuel? Going beyond biofuels. Land Use Policy 2016, 56, 320-326. [CrossRef]

117. Meyer, R.; Priefer, C. Energiepflanzen und Flächenkonkurrenz: Indizien und Unsicherheiten. GAIA 2015, 24, 108-118. [CrossRef]

118. Bos, H.L.; Sanders, J.P.M. Raw material demand and sourcing options for the development of a bio-based chemical industry in Europe. Part 1: Estimation of maximum demand. Biofuels Bioprod. Bioref. 2013, 7, 246-259. [CrossRef]

119. Sanders, J.P.M.; Bos, H.L. Raw material demand and sourcing options for the development of a bio-based chemical industry in Europe. Part 2: Sourcing options. Biofuels Bioprod. Bioref. 2013, 7, 260-272. [CrossRef]

120. Schipfer, F.; Kranzl, L.; Leclère, L.; Forsell, N.; Valin, H. Advanced biomaterials scenarios for the EU28 up to 2050 and their respective biomass demand. Biomass Bioenergy 2017, 96, 19-27. [CrossRef]

121. O'Brien, M.; Schütz, H.; Bringezu, S. The land footprint of the EU bioeconomy: Monitoring tools, gaps and needs. Land Use Policy 2015, 47, 235-246. [CrossRef]

122. De Schutter, L.; Lutter, S. The True Cost of Consumption, The EU's Land Foodprint; Friends of the Earth Europe: Brussels, Belgium, 2016; Available online: http://www.foeeurope.org/sites/default/files/resource_use/20 16/foee-true-cost-consumption-land-footprint.pdf (accessed on 24 May 2017).

123. Mathews, J.A. From the petroeconomy to bioeconomy: Integrating bioenergy production with agricultural demands. Biofuels Bioprod. Bioref. 2009, 3, 613-632. [CrossRef]

124. Kline, K.L.; Msangi, S.; Dale, V.H.; Woods, J.; Souza, G.M.; Osseweijer, P.; Clancy, J.S.; Hilbert, J.A.; Johnson, F.X.; McDonnell, P.C.; et al. Reconciling food security and bioenergy: Priorities for action. GCB Bioenergy 2016, 8, 1-20. [CrossRef]

125. Fachagentur Nachwachsende Rohstoffe (FNR). Biomassepotentiaziale von Rest- und Abfallstoffen. Status Quo in Deutschland; Schriftenreihe Nachwachsende Rohstoffe Band 36. FNR: Gülzow, Germany, 2015. Available online: https://mediathek.fnr.de/downloadable/download/sample/sample_id/1251/ (accessed on 24 May 2017).

126. Brosowski, A.; Thrän, D.; Mantau, U.; Mahro, B.; Erdmann, G.; Adler, P.; Stinner, W.; Reinhold, G.; Hering, T.; Blanke, C. A review of biomass potential and current utilisation-Status quo for 93 biogenic wastes and residues in Germany. Biomass Bioenergy 2016, 95, 257-272. [CrossRef]

127. Liska, A.J.; Yang, H.; Milner, M.; Goddard, S.; Blanco-Canqui, H.; Pelton, M.P.; Fang, X.X.; Zhu, H.; Suyker, A.E. Biofuels from crop residue can reduce soil carbon and increase $\mathrm{CO}_{2}$ emissions. Nat. Clim. Chang. 2014, 4, 398-401. [CrossRef] 
128. Kurian, J.K.; Nair, G.R.; Hussain, A.; Raghavan, G.S.V. Feedstocks, logistics and pre-treatment processes for sustainable lignocellulosic biorefineries: A comprehensive review. Renew. Sustain. Energy Rev. 2013, 25, 205-219. [CrossRef]

129. Dale, B. A sober view of the difficulties in scaling cellulosic biofuels. Biofuels Bioprod. Bioref. 2017, 11, 5-7. [CrossRef]

130. Van Dam, J.; Junginger, M.; Faaij, A.P.C. From the global efforts on certification of bioenergy towards an integrated approach based on sustainable land use planning. Renew. Sustain. Energy Rev. 2010, 4, 2445-2472. [CrossRef]

131. Knudsen, M.T.; Hermansen, J.E.; Thostrup, L.B. Mapping Sustainability Criteria for the Bioeconomy. Available online: http://pure.au.dk/portal/files/93733412/Mapping_Sustainability_Criteria_for_the_Bi oeconomy_final_20.10.2015.pdf (accessed on 24 May 2017).

132. Dale, V.H.; Efroymson, R.A.; Kline, K.L.; Davitt, M.S. A framework for selecting indicators of bioenergy sustainability. Biofuels Bioprod. Bioref. 2015, 9, 435-446. [CrossRef]

133. Thiffault, E.; Endres, J.; McCubbins, J.S.N.; Junginger, M.; Lorente, M.; Fritsche, U.; Iriarte, L. Sustainability of forest bioenergy feedstock supply chains: Local, national and international policy perspectives. Biofuels Bioprod. Bioref. 2015, 9, 283-292. [CrossRef]

134. Selbmann, K.; Pforte, L. Evaluation of Ecological Criteria of Biofuel Certification in Germany. Sustainability 2016, 8, 936. [CrossRef]

135. Van Oorschot, M.; Kok, M.; Brons, J.; van der Esch, S.; Janse, J.; Rood, T.; Vixseboxse, E.; Wilting, H.; Vermeulen, W. Sustainability of International Dutch Supply Chains-Progress, Effects and Perspectives; PBL Netherlands Environmental Assessment Agency: The Hague, The Netherlands, 2014; Available online: http:/ /www.pbl.nl/sites/default/files/cms/PBL_2014_Sustainability\%20of\%20internat ional\%20Dutch\%20supply\%20chains_1289.pdf (accessed on 24 May 2017).

136. Fritsche, U.R.; Iriarte, L. Sustainability Criteria and Indicators for the Bio-Based Economy in Europe: State of Discussion and Way Forward. Energies 2014, 7, 6825-6836. [CrossRef]

137. Ahlgren, S.; Di Lucia, L. Indirect land use changes of biofuel production-A review of modelling efforts and policy developments in the European Union. Biotechnol. Biofuels 2014, 7, 35. [CrossRef] [PubMed]

138. Sluka, C.; Peck, P.C. Stakeholder dynamics in the EU forest energy sector: Key issues to manage and ways forward. Biofuels Bioprod. Bioref. 2015, 9, 51-71. [CrossRef]

139. Piotrowski, S.; Carus, M.; Essel, R. Global Bioeconomy in the Conflict between Biomass Supply and Demand; Nova paper 7; Nova Institut: Hürth, Germany, 2015; Available online: http:/ /bio-based.eu/ecology/\#top (accessed on 24 May 2017).

140. Godfray, H.C.J.; Beddington, J.R.; Crute, I.R.; Haddad, L.; Lawrence, D.; Muir, J.F.; Pretty, J.; Robinson, S.; Thomas, S.M.; Toulmin, C. Food Security: The Challenge of Feeding 9 Billion People. Science 2010, 327, 812-818. [CrossRef] [PubMed]

141. HLPE. Food Losses and Waste in the Context of Sustainable Food Systems. HLPE Report 8. A Report by the High Level Panel of Experts on Food Security and Nutrition of the Committee on World Food Security: Rome 2014. Available online: http://www.fao.org/fileadmin/user_upload/hlpe/hlpe_documents/HLPE_ Reports/HLPE-Report-8_EN.pdf (accessed on 24 May 2017).

142. Aleksandrowicz, L.; Green, R.; Joy, E.J.M.; Smith, P.; Haines, A. The Impacts of Dietary Change on Greenhouse Gas Emissions, Land Use, Water Use, and Health: A Systematic Review. PLoS ONE 2016, 11, e0165797. [CrossRef]

143. Meier, T.; Christen, O.; Semler, E.; Jahreis, G.; Voget-Kleschin, L.; Schrode, A.; Artmann, M. Balancing virtual land imports by a shift in the diet. Using a land balance approach to assess the sustainability of food consumption. Germany as an example. Appetite 2014, 74, 20-34. [CrossRef] [PubMed]

144. Levidow, L. Agricultural Innovation: Sustaining What Agriculture? For What Bio-Economy? Project-Wide Final Report "Co-operative Research on Environmental Problems in Europe (CREPE)"; Open Universität: Milton Keynes, 2011; Available online: http:/ / crepeweb.net/wp-content/uploads/2011/02/crepe_final_report.pdf (accessed on 24 May 2017).

145. Levidow, L.; Birch, K.; Papaioannou, T. Divergent Paradigms of European Agro-Food Innvoation: The Knowledge-Based Bio-Economy (KBBE) as an R\&D Agenda. Sci. Technol. Hum. Values 2012, 38, 94-125. 
146. Lewidow, L. European transition towards a corporate-environmental food regime: Agroecological incorporation or contestation? J. Rural Stud. 2015, 40, 76-89.

147. Shortall, O.K.; Raman, S.; Millar, K. Are plants the new oil? Responsible innovation, biorefining and multipurpose agriculture. Energy Policy 2015, 86, 360-368. [CrossRef]

148. Bugge, M.M.; Hansen, T.; Klitkou, A. What Is the Bioeconomy? A Review of the Literature. Sustainability 2016, 8, 691. [CrossRef]

149. Marsden, T. Third Natures? Reconstituting Space through Place-making Strategies for Sustainability. Int. J. Sociol. Agric. Food 2012, 19, 257-274.

150. Priefer, C.; Jörissen, J.; Frör, O. Pathways to Shape the Bioeconomy. Resources 2017, 6, 10. [CrossRef]

151. Vanloqueren, G.; Baret, P.V. How agricultural research systems shape a technological regime that develops genetic engineering but locks out agroecological innovations. Res. Policy 2009, 38, 971-983. [CrossRef]

152. Borras, S.M., Jr.; Franco, J.C.; Isakson, S.R.; Levidow, L.; Vervest, P. The rise of flex crops and commodities: Implications for research. J. Peasant Stud. 2016, 43, 93-115. [CrossRef]

153. Schmid, O.; Padel, S.; Levidow, L. The Bio-Economy Concept and Knowledge Base in a Public Goods and Farmer Perpective. Bio-Based Appl. Econ. 2012, 1, 47-63.

154. Bos, H.L.; Slingerland, M.A.; Elbersen, W.; Rabbinge, R. Beyond agrification: Twenty-five years of policy and innovation for non-food application of renewable resources in the Netherlands. Biofuels Bioprod. Bioref. 2008, 2, 343-357. [CrossRef]

155. Bringezu, S. Carbon Recycling for Renewable Materials and Energy Supply, Recent Trends, Long-Term Options, and Challenges for Research and Development. J. Ind. Ecol. 2014, 18, 327-340. [CrossRef]

156. Kaup, F.; Selbmann, K. The seesaw of Germany's biofuel policy-Tracing the evolvement to its current state. Energy Policy 2013, 62, 513-521. [CrossRef]

157. Mohr, A.; Raman, S. Lessons from first generation biofuels and implications for the sustainability appraisal of second generation biofuels. Energy Policy 2013, 63, 114-122. [CrossRef] [PubMed]

158. Raman, S.; Mohr, A. Biofuels and the role of space in sustainable innovation journeys. J. Clean. Prod. 2014, 65, 224-233. [CrossRef] [PubMed]

(C) 2017 by the author. Licensee MDPI, Basel, Switzerland. This article is an open access article distributed under the terms and conditions of the Creative Commons Attribution (CC BY) license (http:/ / creativecommons.org/licenses/by/4.0/). 